\title{
Design and Performance of Rigid Nanosize Multimetallic Cartwheel Pincer Compounds as Lewis-Acid Catalysts
}

\author{
Harm P. Dijkstra, ${ }^{\dagger}$ Michel D. Meijer ${ }^{\dagger}{ }^{\prime} \mathrm{im}$ Patel ${ }^{\ddagger}{ }^{\ddagger}$ Rob Kreiter, ${ }^{\dagger}$ \\ Gerard P. M. van Klink, ${ }^{\dagger}$ Martin Lutz, ${ }^{\S}$ Anthony L. Spek, ${ }^{\S, l}$ Allan J . Canty, ${ }^{\ddagger}$ and \\ Gerard van Koten*,† \\ Debye Institute, Department of Metal-Mediated Synthesis, Utrecht University, \\ Padualaan 8, $3584 \mathrm{CH}$ Utrecht, The Netherlands, School of Chemistry, \\ University of Tasmania, Hobart, Tasmania 7001, Australia, and \\ Bijvoet Center for Biomolecular Research, Department of Crystal and \\ Structural Chemistry, Utrecht University, Padualaan 8, \\ $3584 \mathrm{CH}$ Utrecht, The Netherlands
}

Received March 1, 2001

\begin{abstract}
Novel strategies for the preparation of rigid cartwheel pincer metal complexes have been developed. The aromatic backbone of these materials ensures a high rigidity, which is expected to be important for a high retention when these multimetallic nanosize complexes are applied as homogeneous catalysts in a nanomembrane reactor. The ligand precursors $\mathrm{C}_{6}\left[\mathrm{C}_{6} \mathrm{H}_{3}\left(\mathrm{CH}_{2} \mathrm{Y}\right)_{2}-3,5\right]_{6}\left(\mathbf{1 0}, \mathrm{Y}=\mathrm{NMe}_{2} ; \mathbf{1 1}, \mathrm{Y}=\mathrm{SPh} ; \mathbf{1 2}, \mathrm{Y}=\mathrm{PPh}_{2} ; \mathbf{1 3}, \mathrm{Y}=\mathrm{pz}=\right.$ pyrazol-1-yl) have been prepared in high yields from the key intermediate $\mathrm{C}_{6}\left[\mathrm{C}_{6} \mathrm{H}_{3}\left(\mathrm{CH}_{2} \mathrm{Br}\right)_{2}-3,5\right]_{6}$ (9). The hexakis(pincer) palladium(II) complexes $\mathrm{C}_{6}\left[(\mathrm{PdX})-4-\mathrm{C}_{6} \mathrm{H}_{2}\left(\mathrm{CH}_{2} \mathrm{Y}\right)_{2}-3,5\right]_{6}(\mathbf{1 4}, \mathrm{Y}=\mathrm{SPh}, \mathrm{L}=$ $\mathrm{Cl}$; 15, $\mathrm{Y}=\mathrm{PPh}_{2}, \mathrm{~L}=\mathrm{Cl}$; 16, $\mathrm{Y}=$ pyrazol-1-yl, $\mathrm{L}=\mathrm{OAC}$; 17, $\mathrm{Y}=$ pyrazol-1-yl, $\mathrm{L}=\mathrm{Cl}$ ) have been prepared via direct electrophilic palladation of the corresponding ligands. The (tris)pincer ligand $\mathrm{C}_{6} \mathrm{H}_{3}\left[\mathrm{Br}-4-\mathrm{C}_{6} \mathrm{H}_{3}\left(\mathrm{CH}_{2} \mathrm{NMe}_{2}\right)_{2}-3,5\right]_{3}-1,3,5$ (20) was prepared via a triplecondensation reaction of 4-bromo-3,5-bis[(dimethylamino)methyl ]acetophenone (19). Reaction of 20 with $\mathrm{Pd}(\mathrm{dba})_{2}$ yiel ded the tripalladium complex $\mathrm{C}_{6} \mathrm{H}_{3}\left[(\mathrm{PdBr})-4-\mathrm{C}_{6} \mathrm{H}_{3}\left(\mathrm{CH}_{2} \mathrm{NMe}_{2}\right)_{2}-3,5\right]_{3}-$ 1,3,5 (21). The crystal structure of $\mathbf{2 1}$ shows a propeller-like structure with $\mathrm{D}_{3}$ symmetry and a fixed bromine-bromine distance of $17.4573(4) \AA$, approximately forming a triangle with a height of $15.2 \AA$. These nanosize cartwheel pincer metal complexes based on tridentate $Y, C, Y^{\prime}$ pincer ligands have been used as homogeneous Lewis-acid catalysts. Moreover, the influence of the donor substituent $Y$ on the catalytic activity of cationic mono-Y,C,Y' $\mathrm{Pd}^{\prime \prime}{ }^{\prime \prime}$ complexes as Lewis-acid catalysts in the double Michael reaction between methyl vinyl ketone and ethyl $\alpha$-cyanoacetate, as a model reaction, has been investigated. It was found that cationic N,C,N'-type pincer complexes $\left(\mathbf{l a}, \mathrm{Y}=\mathrm{NMe}_{2} ; \mathbf{1 b}, \mathrm{Y}=\mathrm{pz} ; \mathbf{1} \mathbf{c}, \mathrm{Y}=\mathrm{pz} \mathbf{z}^{*}=\right.$ 3,5-dimethyl pyrazol-1-yl; 23) were superior to the $P, C, P^{\prime}$ - and S,C, $S^{\prime}$-pincer complexes (1d, $\mathrm{Y}=\mathrm{PPh}_{2} ; \mathbf{1 e}, \mathrm{Y}=\mathrm{SPh}$ ). The nanosize cationic tri-N $, \mathrm{C}, \mathrm{N}^{\prime} \mathrm{Pd} \mathrm{d}^{\prime \prime}$ complex $\mathbf{2 3}$ was found to have a catalytic activity per catalytic site in the double Michael reaction of the same order of magnitude as the monopincer analogue $1 \mathbf{l a}\left(\mathrm{k}=279 \times 10^{-6} \mathrm{~s}^{-1}\right.$ for $\mathbf{l a}$ vs $\mathrm{k}=232 \times 10^{-6} \mathrm{~s}^{-1}$ for 23). The combination of the nanosize dimensions, the catalytic activity, and the high thermal and air stability makes these complexes excellent candidates for application in a continuous process in a nanomembrane reactor.
\end{abstract}

\section{Introduction}

Within the field of homogeneous catalysis there is currently a great interest in the application of tailored/ engineered organic compounds as soluble support materials for anchored, catalytically active metal complexes. ${ }^{1}$ These organic materials often have a periphery

* To whom correspondence should be addressed. Tel: +3130 2533120. Fax: +31302523615. E-mail: g.vankoten@chem.uu.nl.

+ Debye Institute, Utrecht University.

₹ School of Chemistry, University of Tasmania.

$\S$ Bijvoet Center for Biomolecular Research, Utrecht University.

"Address correspondence pertaining to crystallographic studies to this author. E-mail: A.L.Spek@chem.uu.nl.

(1) F or a review on the application of metallodendrimers as homogeneous catalysts, see: Kreiter, R.; Kleij, A. W.; Klein Gebbink, R. J . M.; van Koten, G. Topics in Current Chemistry, Dendrimers IV by Prof. Dr. F. Vögtle. bearing multidentate ligands or ligand precursors. Their design is usually such that the resulting multimetallic system can easily be recovered for reuse after catalysis from the product-containing solution. ${ }^{2}$ Recently, we and others reported the development of nanosize multimetal homogeneous catalysts, which were separable from the reaction mixture by nanomembrane filtration. ${ }^{2 \mathrm{~d}-\mathrm{g}, \mathrm{j}}$ These catalysts are based on metalated phosphine ligands, ${ }^{2 \mathrm{~d}, \mathrm{e}, \mathrm{g}}$ $P, O$ ligands, ${ }^{2 f}$ or tridentate $Y, C, Y^{\prime}$ ligands ${ }^{2 j}$ (so-called "pincer" ligands) immobilized on large organic frameworks, e.g. carbosilane dendrimers.

In organic synthesis, transition-metal complexes acting as Lewis-acid catalysts have received considerable attention in recent years. ${ }^{3-7}$ Tridentate $Y, C, Y^{\prime}$ pincer ligands in combination with group VIII metals (A; 


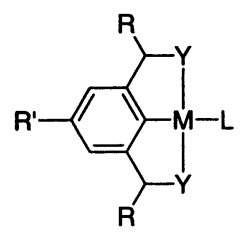

$\mathrm{Y}=\mathrm{NR}_{2}, \mathrm{PR}_{2}, \mathrm{SR}$

$\mathrm{M}=\mathrm{Pd}, \mathrm{Pt}, \mathrm{Ni}, \mathrm{Ru}, \mathrm{Rh}, \mathrm{Ir}$

$\mathrm{R}=$ alkyl

$\mathrm{R}^{\prime}=$ alkyl, OR, dendrimer, fullerenes

A

\section{Figure 1.}

Figure 1) have been found to be active as homogeneous Lewis-acid catalysts as well. ${ }^{8-10}$ Venanzi and Zhang have reported on the use of chiral $\mathrm{P}, \mathrm{C}, \mathrm{P}^{\prime}$-type complexes as catalysts in the aldol reaction between benzal dehydes and methyl isocyanoacetate. ${ }^{8}$ Zhang has also reported that the palladium complexes exhibit a higher activity than the analogous platinum complexes in this reaction. The use of a chiral palladated 1,3-bis(2-oxazolinyl)benzene complex in an aldol reaction, as well as in a single and double Michael reaction, has been reported by Stark et al. ${ }^{9}$ The same ligand on rhodium has been used by Nishiyama and co-workers in the enantioselective allylation of aldehydes. ${ }^{10}$ Although palladated oxa-

(2) (a) Knapen, J . W. J .; van der Made, A. W.; de Wilde, J . C.; van Leeuwen, P. W. N. M.; Wijkens, P.; Grove, D. M.; van Koten, G. Nature 1994, 372, 659. (b) Kragl, U.; Dreisbach, C. Angew. Chem., Int. Ed. Engl. 1996, 35, 642. (c) Reetz, M. T.; Lohmer, G.; Schwickardi, R. Angew. Chem., Int. Ed. 1997, 36, 1526. (d) Giffels, G.; Beliczey, J . Felder, M.; Kragl, U. Tetrahedron: Asymmetry 1998, 9, 691. (e) Brinkmann, N.; Giebel, D.; Lohmer, G.; Reetz, M. T.; Kragl, U. J . Catal . 1999, 183, 163. (f) Hovestad, N.J .; Eggeling, E. B.; Heidbüchel, H. J .; J astrzebski, J . T. B. H.; Kragl. U.; Keim, W.; Vogt, D.; van Koten, G. Angew. Chem., Int. Ed. 1999, 38, 1655. (g) De Groot, D.; Eggeling, E. B.; de Wilde, J . C.; Kooijman, H.; van Haaren, R. J .; van der Made, A. W.; Spek, A. L.; Vogt, D.; Reek, J. N. H.; Kamer, P. C. J .; van Leeuwen, P. W. N. M. Chem. Commun. 1999, 1623. (h) Dijkstra, H. P. Steenwinkel, P.; Grove, D. M.; Lutz, M.; Spek, A. L.; van Koten, G. Angew. Chem., Int. Ed. 1999, 38, 2186. (i) Albrecht, M.; Hovestad, N. J .; Boersma, J',; van Koten, G. Chem. Eur. J . 2001, 7, 1289. (j) Kleij, A. W.; Gossage, R. A.; Klein Gebbink, R. J . M.; Brinkman, N.; Reijerse E. J .; Kragl, U.; Lutz, M.; Spek, A. L.; van Koten, G. J . Am. Chem. Soc. 2000, 122, 12112

(3) (a) Mahrwald, R. Chem. Rev. 1999, 99, 1095 and references therein. (b) Christoffers, J. Eur. J. Org. Chem. 1998, 1259 and references therein. (c) Drury, W. J .; Ferraris, D.; Cox, C.; Young, B.; Lectka, T. J. Am. Chem. Soc. 1998, 120, 11006.

(4) Diels-Alder Reactions: (a) Bruin, M. E.; Kündig, E. P. Chem. Commun. 1998, 2635. (b) Kanemasa, S.; Oderaotoshi, Y.; Sakaguchi, S.-I.; Yamamoto, H.; Tanaka, J .; Wada, E.; Curran, D. J. Am. Chem. Soc. 1998, 120, 3074. (c) Schaus, S. E.; Brắnalt, J .; J acobsen, E. N. J Org. Chem. 1998, 63, 403. (d) Davies, D. L.; Fawcett, J .; Garrat, S. A.; Russell, D. R. Chem. Commun. 1997, 1351. (e) Evans, D. A.; Murry, J A.; von Matt, P.; Norcross, R. D.; Miller, S. J . Angew. Chem., Int. Ed. Engl. 1995, 34, 798. (f) Kündig, E. P.; Bourdin, B.; Bernardinelli, G. Angew. Chem., Int. Ed. Engl. 1994, 33, 1856. (g) Corey, E. J .; I mai, N.; Zhang, H.-Y. J . Am. Chem. Soc. 1991, 113, 728.

(5) Aldol reactions: (a) Fujimura, O. J . Am. Chem. Soc. 1998, 120 10032. (b) Evans, D. A.; MacMillan, D. W. C.; Campos, K. R. J . Am Chem. Soc. 1997, 119, 10859. (c) Yanagisawa, A.; Matsumoto, Y.; Nakashima, H.; Asakawa, K.; Yamamoto, H. J . Am. Chem. Soc. 1997, 119, 9319. (d) Evans, D. A.; Murry, J. A.; Kozlowski, M. C. J . Am. Chem. Soc. 1996, 118, 5814. (e) Mikami, K.; Matsukawa, S. J . Am. Chem. Soc. 1994, 116, 4077.

(6) Michael reactions: (a) Blacker, A. J .; Clarke, M. L.; Loft, M. S.; Mahon, M. F.; Williams, J. M. J . Organometallics 1999, 18, 2867. (b) Sawamura, M.; Hamashima, H.; I to, Y. Tetrahedron 1994, 50, 4439. (c) Evans, D. A.; Rovis, T.; Kozlowski, M. C.; Wade Downey, C.; Tedrow, J. S. J . Am. Chem. Soc. 2000, 122, 9134.

(7) Alkylation reactions: (a) Ferraris, D.; Young, B.; Dudding, T.; Lectka, T. J . Am. Chem. Soc. 1998, 120, 4548. (b) Yanagisawa, A.; Nakashima, H.; Ishiba, A.; Yamamoto, H. J. Am. Chem. Soc. 1996, 118,4723

(8) (a) Gorla, F.; Togni, A.; Venanzi, L. M.; Albinati, A.; Lianza, F. Organometallics 1994, 13, 1607. (b) Longmire, J. M.; Zhang, X.; Shang, M. Organometallics 1998, 17, 4374.

(9) (a) Stark, M. A.; Richards, C. J . Tetrahedron Lett. 1997, 38, 5881. (b) Stark, M. A.; J ones, G.; Richards, C. J . Organometallics 2000, 19, 1282.

(10) Motoyama, Y.; Narusawa, H.; Nishiyama, H. Chem. Commun. 1999, 131.

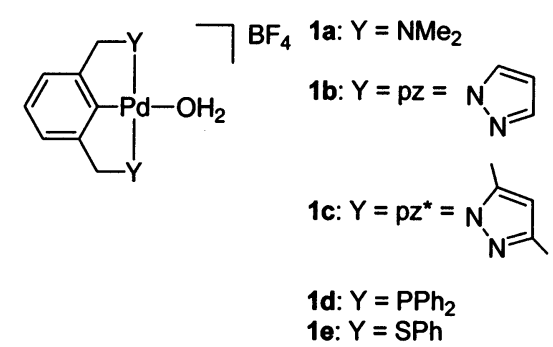

Figure 2.

zolinyl-based pincer complexes ${ }^{9}$ appear to be more active in the aldol reaction than the corresponding $\mathrm{P}, \mathrm{C}, \mathrm{P}^{\prime}$ anal ogue, ${ }^{8 b}$ a detailed investigation into the influence of the donor group $Y$ on the catalyst activity has not been reported thus far.

The lack of understanding of the influence of the donor substituent $Y$ (Figure 1 ) on the activity of the Lewis-acid catalyst impedes the rational design of effective catalysts of the form A. For the design and synthesis of nanosize homogeneous catalysts based on pincer metal building blocks for organic reactions, knowledge about this aspect is important. Thus, we have undertaken such a study by varying $Y$ in complexes $\mathbf{1 a}-\mathbf{e}$ (Figure 2) and investigated the catalytic activity of these complexes in the double Michael reaction between methyl vinyl ketone and ethyl $\alpha$-cyanoacetate as a model reaction. While a direct comparison is not entirely valid, since the substituents attached to the different donor atoms are not equivalent in all cases (e.g. the pincer complex with $\mathrm{Y}=\mathrm{NPh}_{2}$ cannot be prepared), this series can give a good indication of the overall effect of the donor atom (N, $\mathrm{P}$, or $\mathrm{S})$ on the activity of the catalyst. Furthermore, complexes $\mathbf{1 b}(\mathrm{Y}$ $=\mathrm{pz}=$ pyrazol-1-yl) and $\mathbf{1 c}(\mathrm{Y}=\mathrm{pz} *=3,5$-dimethyl pyrazol-1-yl) can also provide additional information about the influence of the electron-donating methyl groups on the activity of the Lewis-acid catalyst. In addition, we report here the application of multipincer complexes as nanosize homogeneous catalysts in the same double Michael reaction. For this study, rigid multipincer benzene complexes $\mathbf{B}^{2 \mathrm{~h}}$ and $\mathbf{C}$ (Figure 3) were selected incorporating six and three palladated pincer groups, respectively. An obvious difference be tween $\mathbf{B}$ and $\mathbf{C}$ is the lower degree of congestion about the metal centers in the tripalladium cartwheel complex. We expect that a high degree of rigidity in the backbone of these nanosize catalysts is advisable for optimal retention of such materials by nanomembrane filters.

\section{Results and Discussion}

Synthesis of Monopincer Complexes. Complexes $\mathbf{1 a}-\mathbf{e}$ were prepared from the corresponding palladium halide complexes $\mathbf{3 a}-\mathbf{e}$ by reaction with silver tetrafluoroborate in wet acetone (Scheme 1). ${ }^{11-13}$ The palladium chloride complex $3 c$ was prepared via direct electrophilic palladation, using $\mathrm{Pd}(\mathrm{OAc})_{2}$ in refluxing acetic acid, ${ }^{14}$ while complexes 3d,e were prepared according to literature procedures. 15

Different routes were developed for the synthesis of metalated hexakis(pincer)- and (tris)pincer-substituted benzenes (B and $\mathbf{C}$, respectively, Figure 3), which are rigid nanosize molecules potentially suitable for recov- 


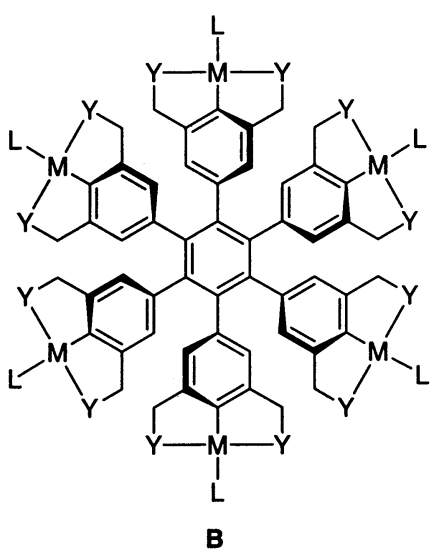<smiles>[Y]Cc1cc(-c2cc(-c3cc(C[Y])c([Y]([X])([H])[H])c(C[Y])c3)cc(-c3cc(C[Y])c([Y]([X])([H])[H])c(C[Y])c3)c2)cc(C[Y])c1[X]</smiles>

C

Figure 3.

\section{Scheme $1^{\mathrm{a}}$}

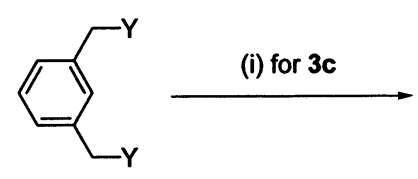

2c: $Y=p z^{*}$

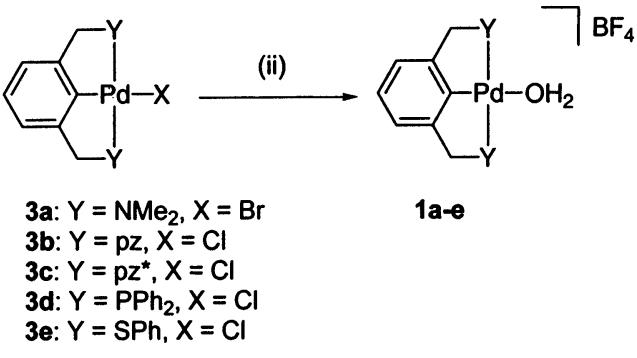

a Conditions: (i) $\mathrm{Pd}(\mathrm{OAC})_{2}$, acetic acid, reflux, $18 \mathrm{~h}$, followed by $\mathrm{LiCl}$, acetone, room temperature, $2 \mathrm{~h}$; (ii) $\mathrm{AgBF}_{4}$, acetonel water, room temperature, $1 \mathrm{~h}$.

ery by nanomembrane filtration. Recently, we reported the first synthesis of a fully palladated hexakis(pincer) complex (B, M = Pd, Y = SPh, L = Cl; Figure 3) and its molecular geometry in the solid state. ${ }^{2 \mathrm{~h}}$ In this study, the preparation of palladated hexakis(pincer) complexes having a variety of different coordinative ligands and the synthesis of novel tripalladated pincer complexes have been carried out.

Synthesis of Hexakis(pincer) Compounds. The various hexakis(pincer) ligands $\mathrm{C}_{6}\left[\mathrm{C}_{6} \mathrm{H}_{3}\left(\mathrm{CH}_{2} \mathrm{Y}\right)_{2}-3,5\right]_{6}$ (10-13) can be prepared using dodecabromide $\mathrm{C}_{6}$ $\left[\mathrm{C}_{6} \mathrm{H}_{3}\left(\mathrm{CH}_{2} \mathrm{Br}\right)_{2}-3,5\right]_{6}(\mathbf{9})$ as the key synthetic intermediate. The synthesis of $\mathbf{9}$ was first reported by Duchêne and Vögtle, ${ }^{16}$ but this route invol ved a number of timeconsuming and expensive column chromatography tech- niques. Therefore, we developed an improved route to 9, as outlined in Scheme 2, which involves the trimerization of the bis(pincer)acetylene species 7 to hexakis[3,5-bis(methoxymethyl)phenyl ]benzene (8), which can easily be converted to $\mathbf{9}$.

Compound $\mathbf{7}$ was prepared in a one-pot $\mathrm{Pd} / \mathrm{Cu}$ catalyzed cross-coupling reaction starting from iodoarenes 6 and gaseous acetylene (Scheme 2). ${ }^{17}$ This procedure afforded $\mathbf{7}$ in $90 \%$ overall yield, which is a significant improvement over the four-step procedure reported earlier (22\% overall yield for 7$).{ }^{16}$

Conversion of the bis(pincer)acetylene $\mathbf{7}$ in two steps to the key intermediate $\mathbf{9}$ and subsequent introduction of the different donor substituents $Y$ via nucleophilic substitution reactions resulted in the formation of the different hexakis(pincer) ligands 10-13 (Scheme 3).

Metalation of Hexakis(pincer) Ligands. Direct electrophilic palladation of dodecasulfide $\mathbf{1 1}$ and dodecaphosphine $\mathbf{1 2}$ with a small excess of $\left[\mathrm{Pd}(\mathrm{MeCN})_{4}\right]-$ $\left(\mathrm{BF}_{4}\right)_{2}$ in acetonitrile, ${ }^{18}$ followed by addition of $\mathrm{LiCl}$, gave the hexakis(chloropalladium) complexes $\mathbf{1 4}$ and $\mathbf{1 5}$ in 90 and $89 \%$ yields, respectively (Scheme 4$)$. The reaction time needed for complete metalation of $\mathbf{1 1}$ (3 h), however, was considerably shorter than the time needed for $\mathbf{1 2}$ (110 h). Thus far, the hexapal ladium(II) complex 15 has been analyzed by ${ }^{1} \mathrm{H},{ }^{13} \mathrm{C}$, and ${ }^{31} \mathrm{P}$ NMR spectroscopy only; no product found to be pure by elemental analysis has yet been obtained. The analogous dodecasulfide 14 has been characterized by X-ray crystallography, and its molecular structure showed a cartwheel-like structure with $C_{3}$ symmetry and diametrically opposed Pd-Pd separations of $15.340(2) \AA .{ }^{2 h}$

Treatment of dodecapyrazole $\mathbf{1 3}$ with $\mathrm{Pd}(\mathrm{OAC})_{2}$ in acetic acid resulted in the formation of $\mathrm{C}_{6}[(\mathrm{PdOAc})-4-$ $\left.\mathrm{C}_{6} \mathrm{H}_{2}\left(\mathrm{CH}_{2} \mathrm{pz}\right)_{2}-3,5\right]_{6}$ (16), which was isolated in $53 \%$ yield. Reaction of $\mathbf{1 6}$ with $\mathrm{LiCl}$ gave the corresponding hexakis(chloropalladium) complex 17, which upon reaction with $\mathrm{AgBF}_{4}$ in wet acetone afforded the hexakis(aquapalladium) complex $\mathrm{C}_{6}\left[\left\{\mathrm{Pd}\left(\mathrm{OH}_{2}\right)\right\}-4-\mathrm{C}_{6} \mathrm{H}_{2}\left(\mathrm{CH}_{2-}\right.\right.$ $\left.\mathrm{Pz})_{2}-3,5\right]_{6}$ (18) in 70\% yield (Scheme 4).

Complete palladation of hexakis(pincer) ligand $\mathbf{1 0}$ was not feasible via direct electrophilic palladation. Therefore, the palladium centers were introduced via a lithiation-transmetalation method using t-BuLi as the lithiation agent and $\mathrm{PdCl}_{2}\left(\mathrm{SEt}_{2}\right)_{2}$ as the palladium source. Although completelithiation occurred, as shown by a deuteration reaction with $\mathrm{D}_{2} \mathrm{O}$ and subsequent analysis by ${ }^{1} \mathrm{H}$ and ${ }^{13} \mathrm{C}$ NMR spectroscopy, complete palladation via this route also could not be achieved.

(11) F or the synthesis of 3a see: Alsters, P. L.; Baesjou, P. J .; J anssen, M. D.; Kooijman, H.; Sicherer-Roetman, A.; Spek, A. L.; van Koten, G. Organometallics 1992, 11, 4124.

(12) F or the synthesis of $\mathbf{1 b}$ and $\mathbf{3 b}$ see: Canty, A. J .; Honeyman, R. T.; Skelton, B. W.; White, A. H. J . Organomet. Chem. 1990, 389, 277.

(13) F or the synthesis of $\mathbf{1 a}$ from 3a see: Grove, D. M.; van Koten, G.; Louwen, J . N.; Noltes, J . G.; Spek, A. L.; Ubbels, H. J . C. J . J . Am. Chem. Soc. 1984, 104, 6609.

(14) Hartshorn, C. M.; Steel, P. J . Organometallics 1998, 17, 3487.

(15) (a) For the synthesis of $\mathbf{3 d}$ see: Rimml, H.; Venanzi, L. M. J Organomet. Chem. 1983, 259, C6. (b) For the synthesis of 3e see Lucena, N.; Casabo, J .; Escriche, L.; Sanchez-Castello, G.; Teixidor, F.; Kivekäs, R.; Sillanpää, R. Polyhedron 1996, 15, 3009.

(16) Duchêne, K.-H.; Vögtle, F. Synthesis 1986, 659.

(17) Sonogashira, K.; Tohda, Y.; Hagihara, N. Tetrahedron Lett. 1975, 4467.

(18) Procedure reported by: (a) Loeb, S. J .; Shimizu, G. K. H. J . Chem. Soc., Chem. Commun. 1993, 1396. (b) Kickham, J . E.; Loeb, S. J. Inorg. Chem. 1994, 33, 4351. 
Scheme 2. Synthesis of $\mathrm{C}_{6}\left[\mathrm{C}_{6} \mathrm{H}_{3}\left(\mathrm{CH}_{2} \mathrm{Br}\right)_{2}-3,5\right]_{6}$ (9) from 3,5-Dimethylaniline ${ }^{a}$<smiles>CC#Cc1cc(I)cc(C#CC#CC(CC(C)C)c2cc(I)cc(CBr)c2)c1</smiles><smiles>COCc1cc(COC)cc(COC)c1</smiles>

(vi)<smiles>BrCc1cc(CBr)cc(-c2c(-c3cc(CBr)cc(CBr)c3)c(-c3cc(CBr)cc(CBr)c3)c(-c3cc(CBr)cc(CBr)c3)c(-c3cc(CBr)cc(CBr)c3)c2-c2cc(CBr)cc(CBr)c2)c1</smiles>

a Conditions: (i) $25 \% \mathrm{H}_{2} \mathrm{SO}_{4}(\mathrm{aq}), \mathrm{NaNO}_{2}(\mathrm{aq}),-10{ }^{\circ} \mathrm{C}, 30 \mathrm{~min}$, followed by $\mathrm{KI}(\mathrm{aq}),-10 \rightarrow 90{ }^{\circ} \mathrm{C}, 2 \mathrm{~h}$; (ii) $\mathrm{N}$-bromosuccinimide, AIBN, MeOAc, reflux, hv, $12 \mathrm{~h}$; (iii) $\mathrm{NaOMe}, \mathrm{MeOH}$, reflux, $18 \mathrm{~h}$; (iv) $\mathrm{HC} \equiv \mathrm{CH}$, $\left[\mathrm{PdCl}_{2}\left(\mathrm{PPh}_{3}\right)_{2}\right], \mathrm{Cul}_{\text {, }} \mathrm{Et}_{2} \mathrm{NH}$, $18 \mathrm{~h}$, room temperature; (v) $\left[\mathrm{PdCl}_{2}(\mathrm{PhCN})_{2}\right]$, benzene, reflux, $6 \mathrm{~h}$; (vi) $\mathrm{AcBr}, \mathrm{BF}_{3} \cdot \mathrm{OEt}_{2}, \mathrm{CH}_{2} \mathrm{Cl}_{2}$, reflux, $24 \mathrm{~h}$.

\section{Scheme $3^{\mathrm{a}}$}

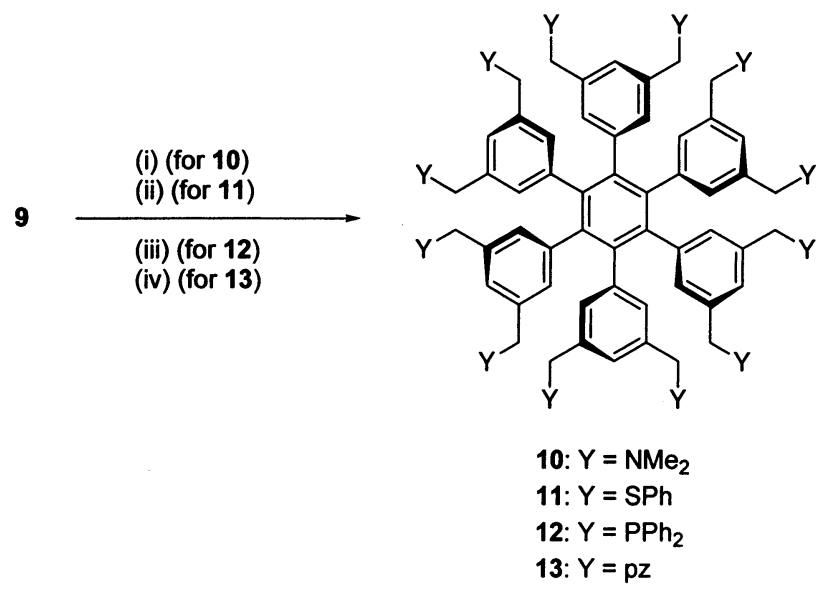

a Conditions: (i) $\mathrm{HNMe}_{2} \mathrm{CH}_{2} \mathrm{Cl}_{2}$, room temperature, $3 \mathrm{~h}$; (ii) $\mathrm{PhSH}, \mathrm{K}_{2} \mathrm{CO}_{3}, \mathrm{DMF}$, room temperature, $18 \mathrm{~h}$; (iii) $\mathrm{HPPh}_{2} \cdot \mathrm{BH}_{3}, \mathrm{n}-\mathrm{BuLi}, \mathrm{THF},-30^{\circ} \mathrm{C} \rightarrow$ room temperature, $18 \mathrm{~h}$, followed by $\mathrm{HBF}_{4} \cdot \mathrm{OEt}_{2}, \mathrm{Et}_{2} \mathrm{O}$, room temperature, $2 \mathrm{~h}$; (iv) pyrazole, K, THF, reflux, $1.5 \mathrm{~h}$, followed by addition of $\mathbf{9}, \mathrm{THF}$, reflux, $15 \mathrm{~h}$.

On average, four to five pincer groups were palladated by this method.

Synthesis of Tris(pincer) Compounds. The synthesis of the tris(pincer) ligand $\mathrm{C}_{6} \mathrm{H}_{3}\left[\mathrm{Br}-4-\mathrm{C}_{6} \mathrm{H}_{3}\left(\mathrm{CH}_{2}-\right.\right.$ $\left.\left.\mathrm{NMe}_{2}\right)_{2}-3,5\right]_{3}-1,3,5$ (20) started from substituted acetophenone 19 (Scheme 5), prepared according to a previous literature procedure. ${ }^{19} \mathrm{~A}$ triple condensation reaction of $\mathbf{1 9}$ with tetrachlorosilane in ethanol afforded 20 in 70\% yield. ${ }^{20}$ Palladation of this tris(pincer) ligand

(19) Van de Kuil, L. A.; Luitjes, H.; Grove, D. M.; Zwikker, J . W. van der Linden, J . G. M.; Roel ofsen, A. M.; J enneskens, L. W.; Drenth, W.; van Koten, G. Organometallics 1994, 13, 471.

(20) Modification of a reported method was used: Elmorsy, S. S. Pelter, A.; Smith, K. Tetrahedron Lett. 1991, 32, 4175.
Scheme 4. Palladation Routes for Various $\mathrm{C}_{6}\left(\mathrm{C}_{6} \mathrm{H}_{3}\left(\mathrm{CH}_{2} \mathrm{Y}\right)_{2}-3,5\right)_{6}$ Ligands $^{\mathrm{a}}$

(i) (for 14 and 15)

(ii) (for 16)

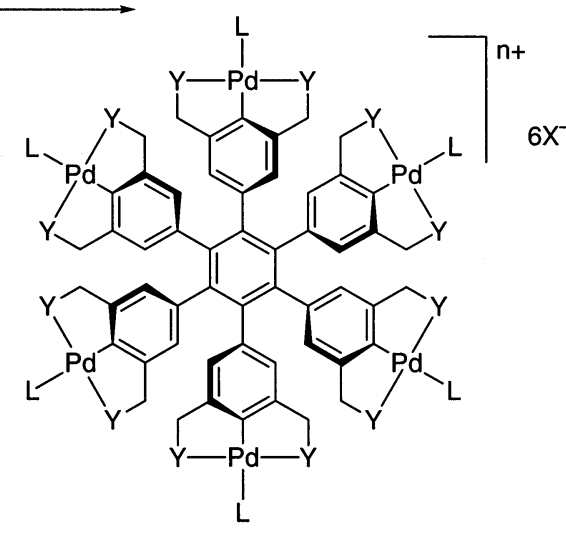

14: $Y=S P h ; L=C l ; n=0$ (no $\left.X^{-}\right)$

15: $Y=P P h_{2} ; L=C l ; n=0$ (noX)

16: $Y=p z ; L=O A c ; n=0\left(n \circ X^{-}\right)$

17: $Y=p z ; L=C l ; n=0$ (no $\left.X^{\prime}\right)$

18: $\left.Y=p z ; L=H_{2} \mathrm{O} ; X=B_{4} ; n=6\right]$ (iv)

a Conditions: (i) $\left[\mathrm{Pd}\left(\mathrm{NCMe}_{4}\right]\left(\mathrm{BF}_{4}\right)_{2}, \mathrm{MeCN}\right.$, reflux, 5-110 $h$, followed by $\mathrm{LiCl}$, acetone, room temperature, $1 \mathrm{~h}$; (ii) $\mathrm{Pd}(\mathrm{OAC})_{2}, \mathrm{AcOH}$, reflux, $15 \mathrm{~h}$; (iii) $\mathrm{LiCl}$, acetone, room temperature, $15 \mathrm{~h}$; (iv) $\mathrm{AgBF}_{4}$, acetone, room temperature, $3 \mathrm{~h}$.

was achieved via an oxidative addition reaction with Pd$(\mathrm{dba})_{2}$, resulting in the formation of palladated tris(pincer) complex $\mathbf{2 1}$ in 70\% yield. The corresponding triplatinum(II) compound $\mathbf{2 2}$ was obtained in $73 \%$ yiel d by reaction of $\mathbf{2 0}$ with $\left[\mathrm{Pt}(\mathrm{tol})_{2} \mathrm{SEt}_{2}\right]_{2}$, a method previously reported. ${ }^{21}$ The neutral complex $\mathbf{2 1}$ can easily be

(21) Canty, A. J .; Patel, J .; Skelton, B. W.; White, A. H. J . Organomet. Chem. 2000, 599, 195. 

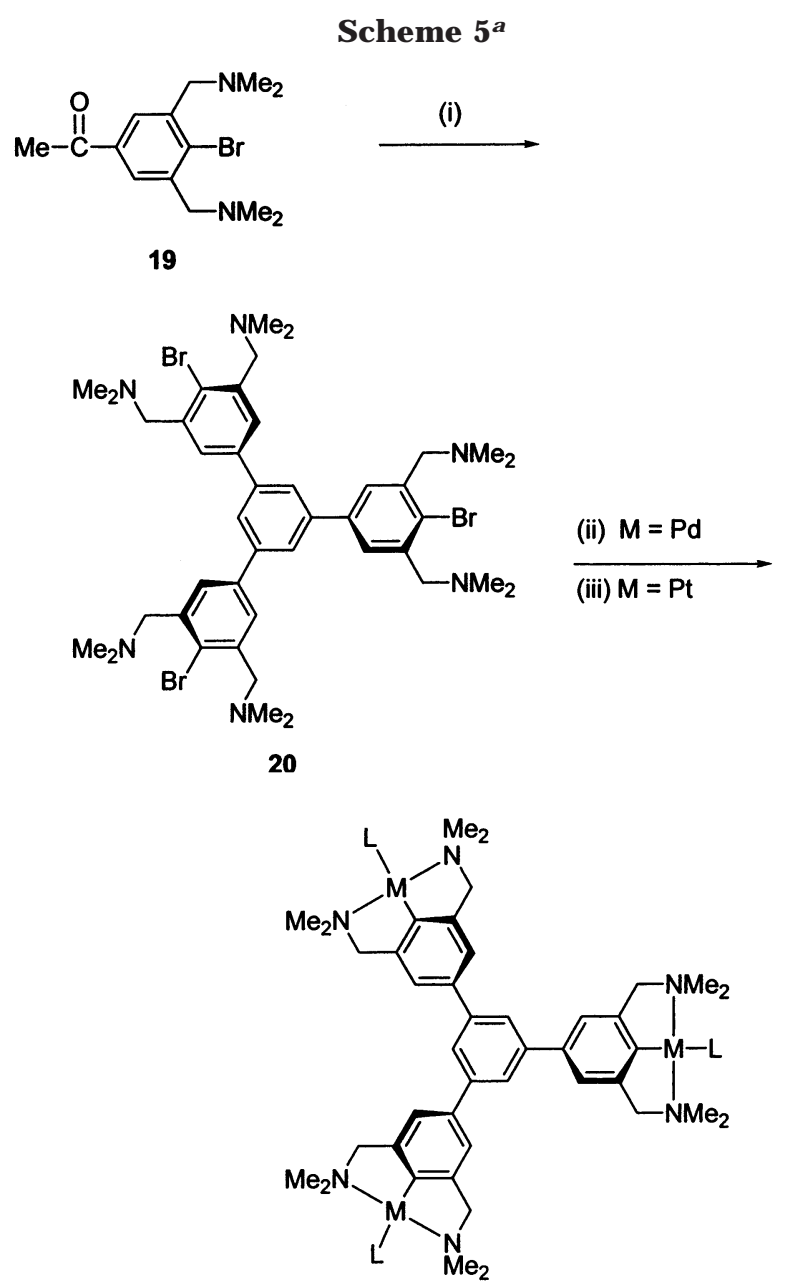

$$
\begin{aligned}
& \text { 21: } M=P d, L=B r \\
& \text { 22: } M=P t, L=B r \\
& \text { 23: } M=P d, L=O H_{2}\left(B F_{4}\right)
\end{aligned}
$$

a Conditions: (i) $\mathrm{SiCl}_{4}, \mathrm{EtOH}$, reflux, $18 \mathrm{~h}$; (ii) $\mathrm{Pd}(\mathrm{dba})_{2}$, benzene, room temperature, $18 \mathrm{~h}$; (iii) $\left[\mathrm{Pt}(\mathrm{tol})_{2} \mathrm{SEt}_{2}\right]_{2}$, benzene, reflux, 3 h; (iv) $\mathrm{AgBF}_{4}$, wet acetone, room temperature, $2 \mathrm{~h}$.

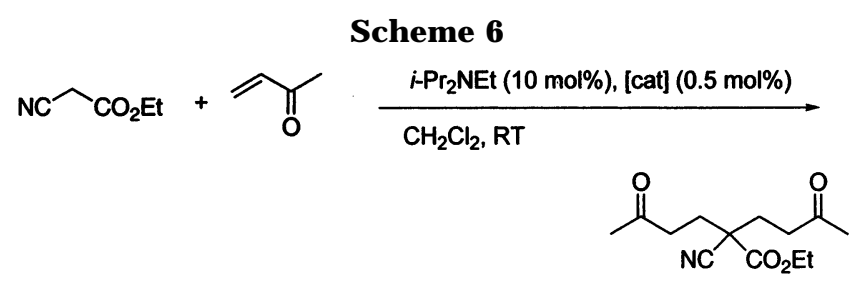

converted to the corresponding triionic aqua complex 23 in 76\% yield by treatment with silver tetrafluoroborate in wet acetone (Scheme 5).

Brownish crystals of $\mathbf{2 1}$ suitable for a crystal structure determination were obtained by slow diffusion of diethyl ether into a concentrated solution of $\mathbf{2 1}$ in methylene chloride. The molecular geometry of $\mathbf{2 1}$ shows a central benzene ring substituted at the 1-, 3-, and 5-positions with diorganoamine moieties each cyclopalladated at the intraannular position between the $\mathrm{CH}_{2} \mathrm{NMe}_{2}$ groups (F igure 4). This affords square-planar Pd"I centers with a ligand environment comprised of tridentate $\mathrm{N}, \mathrm{C}, \mathrm{N}^{\prime}$ coordination by the organic moiety with a bromo ligand trans to the metal-bonded aromatic carbon. Compound $\mathbf{2 1}$ crystallizes in the trigonal space group $\mathrm{R} \overline{\mathrm{z}} \mathrm{c}$ with the molecule on a special position with crystallographic 32 symmetry. This leads to an exact mol ecular symmetry

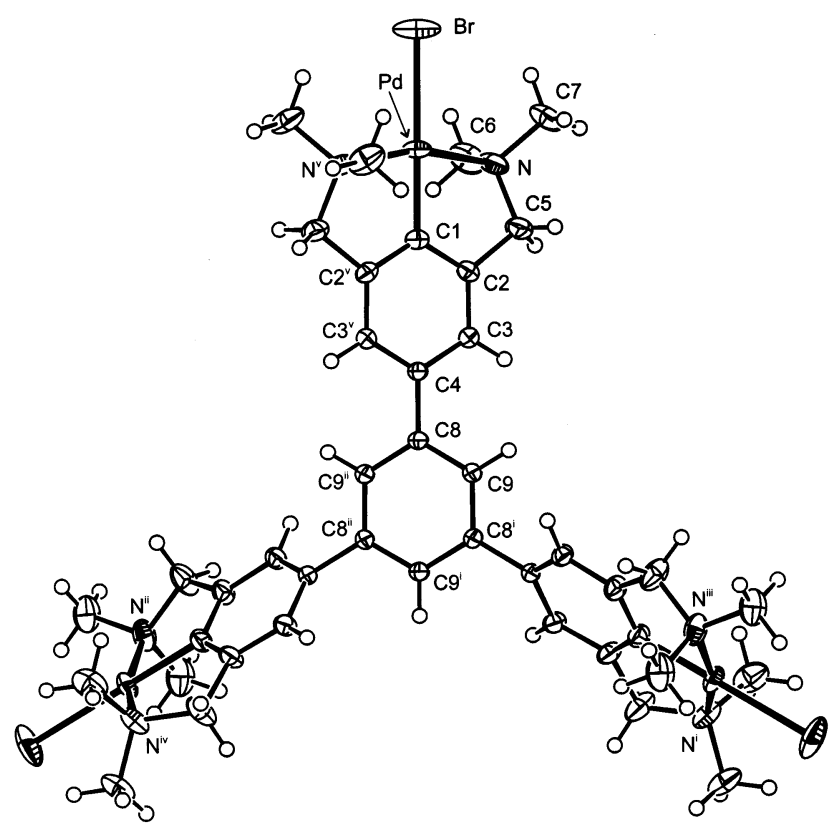

Figure 4. Displacement ellipsoid plot $(50 \%$ probability level) of 21. Symmetry operations: (i) $1-y, x-y, z$; (ii) 1 $-x+y, 1-x, z$; (iii) $1 / 3+y,-1 / 3+x, 1 / 6 z$; (iv) $4 / 3-x, 2 / 3$ $-x+y, 1 / 6-z ;$ (v) $1 / 3+x-y, 2 / 3-y, 1 / 6-z$.

of $D_{3}$. The "pincer" systems are therefore tilted in the same direction with respect to the central benzene ring (twist angle $47.31^{\circ}$ ). The size of the molecule is probably best defined by the fixed bromine-bromine distance of 17.4573(4) A. If we approximate the molecular shape as a triangle, the height of the triangle would be 15.2 $\AA$. The molecules are stacked on top of each other in the direction of the crystallographic $c$ axis with six molecules in one unit cell. We can thus roughly approximate the thickness of the molecule in the crystal with $c / 6=5.9 \AA$.

Although these hexakis- and tris(pincer) complexes have fairly low molecular weights, especially in comparison with dendrimers, the rigid structures result in their true nanoparticle dimensions. These properties make them appropriate catalysts for retention by nanomembrane filters.

Catalysis. Complexes 1a-e were tested as Lewisacid catalysts in the double Michael reaction between ethyl $\alpha$-cyanoacetate and methyl vinyl ketone (Scheme 6) as a model reaction, and the results are summarized in Table 1.

From Table 1 it is clear that pincer complexes based on $\mathrm{N}, \mathrm{C}, \mathrm{N}^{\prime}$-type ligands (1a-c, 23, entries $\mathbf{1 - 3}$ and 6 ) are the most active catalysts in this reaction. The $P, C, P^{\prime}$ pincer complex le (entry 5) shows rather low activity, while the reaction catalyzed by the $S, C, S^{\prime}$ pincer complex 1d (entry 4) is hardly faster than the blank reaction (entry 7). It was also found that the catalytic activity of 1c was considerably higher than the activity of $\mathbf{1 b}$ (entries 2 and 3, respectively). The only difference between the two catalysts is that $\mathbf{1 c}$ contains two methyl substituents in the pyrazolyl group (pz*), making $\mathbf{1 c}$ a weaker Lewis acid than $\mathbf{1 b}$. The effect of the methyl group substitution can be seen by comparing the $\mathrm{pK}_{\mathrm{a}}$ value of 1-Mepz $\left(\mathrm{pK}_{\mathrm{a}}=1.19\right)$ with that of $1,3,5-\mathrm{Me}_{3} \mathrm{pz}$ 
Table 1. Catalytic Activities of the Various Pincer Catalysts in the Double Michael Reaction between Methyl Vinyl Ketone and Ethyl $\alpha$-Cyanoacetate

\begin{tabular}{cccc}
\hline entry & catalyst & $\mathrm{k}\left(10^{-6} \mathrm{~s}^{-1}\right)^{\mathrm{a}}$ & $\mathrm{t}_{1 / 2}(\mathrm{~min})^{\mathrm{b}}$ \\
\hline 1 & la & 279 & 41 \\
2 & $\mathbf{1 b}$ & 134 & 86 \\
3 & $\mathbf{1 c}$ & 348 & 33 \\
4 & $\mathbf{1 d}$ & 4.18 & 2800 \\
5 & $\mathbf{1 e}$ & 9.48 & 1200 \\
6 & $\mathbf{2 3}$ & 232 & 50 \\
7 & blank & 3.78 & 3056
\end{tabular}

a Determined by ${ }^{1} \mathrm{H}$ NMR by comparison of the integration of the $\mathrm{CH}_{2}$ protons of ethyl $\alpha$-cyanoacetate to the combined integration of the ethyl ester $\mathrm{CH}_{2}$ protons of the reactant and product. The reactions are first order in $\mathrm{CN}$ ( $\mathrm{CN}=$ ethyl $\alpha$-cyanoacetate); the rate constant $\mathrm{k}$ was determined by plotting $-\ln \left(\left[\mathrm{CN} /[\mathrm{CN}]_{0}\right)\right.$ versus time (in seconds). ${ }^{b} t_{1 / 2}=\ln 2 /(60 k)$.

$\left(\mathrm{pK}_{\mathrm{a}}=2.90\right){ }^{22}$ Thus, although $\mathbf{1 c}$ is a weaker Lewis acid than $\mathbf{1 b}$, it is the most active catalyst tested in this series and also the most active catalyst of the pincer type reported in the literature so far for this particular reaction. Although the mechanism of this reaction is not yet fully established, this probably means that not a deprotonation step but rather the dissociation of the product or an intermediate from the metal center determines the rate of this reaction, as such a step is expected to be faster for weaker Lewis acids.

Unfortunately, the hexakis(pincer) complex $\mathbf{1 8}$ is not soluble under the reaction conditions used for the double Michael reaction. Nevertheless, 18 did show catalytic activity (70\% after $22 \mathrm{~h}$ ), despite the heterogeneous nature of the reaction. Complex $\mathbf{2 3}$, on the other hand, is soluble under the reaction conditions, and from Table 1 it is clear that the catalytic activity per palladium center of tris(pincer) complex $\mathbf{2 3}$ is al most the same as that of the corresponding monopincer analogue $\mathbf{l a}$ (in all reactions the total numbers of $\mathrm{Pd}$ "l centers were kept equal). Although three catalytic sites are located in a single catalyst particle, this has no significant influence on the catalytic activity of the independent catalytic sites. Thus, with the tris(pincer) systems we have a system in hand which is soluble in common organic solvents and is quite heat- and air-stable.

\section{Conclusions}

New routes have been developed for the synthesis of rigid nanosize organometallic materials based on an aromatic backbone. Hexametallic complexes 14-18 and trimetallic complexes 21-23 have been prepared in good yields and have been fully characterized (except for 15). The molecular structure of $\mathbf{2 1}$ shows a propeller-like structure with a molecular symmetry of $D_{3}$ and a bromine-bromine distance of 17.4573(4) $\AA$.

The cationic N,C,N' palladium(II) complexes are the most active Lewis-acid catalysts of the pincer-type series in the double Michael reaction between ethyl $\alpha$-cyanoacetate and methyl vinyl ketone reported thus far. Comparison of the catalytic activities of $\mathbf{1 b}$ and $\mathbf{1 c}$ demonstrates that the weaker Lewis acid (1c) gives a higher activity in this particular reaction, which may mean that dissociation of the product or an intermediate from the metal center appears as a unique step in the rate law of this reaction. Furthermore, the hexakis-

(22) Canty, A. J .; Lee, C. V. Organometallics 1982, 1, 1063. (pincer) complex $\mathbf{1 8}$ was also active in the double Michael reaction, despite the fact that the catalyst did not dissolve under the reaction conditions. These solubility issues also explain the much lower activity of $\mathbf{1 8}$ relative to its monopincer anal ogue $\mathbf{1 b}$. In contrast, the catalytic activity of the soluble nanosize tricationic catalyst $\mathbf{2 3}$ was found to be similar to that of its monopincer analogue $\mathbf{1 a}$.

As separation of the catalyst will be important in the final catalytic process, we are currently investigating to what extent nanosize pincer catalysts, such as $\mathbf{2 3}$, are retained by nanomembranes. Preliminary results have al ready shown that the platinum analogue $\mathbf{2 2}$ exhibits a retention of approximately $94 \%$ by the MPF 60 membrane, which is quite efficient for such a small molecule. ${ }^{23}$ For continuous processes, however, higher retentions are needed. Thus, we are currently also investigating the synthesis of larger nanosize pincer complexes with rigid cores for use as homogeneous catalysts in continuous nanomembrane reactor processes. $^{23}$

\section{Experimental Section}

Solvents were purified and dried according to standard procedures, stored under a nitrogen atmosphere, and freshly distilled prior to use. NMR solvents were purchased and used without further purification. The complexes $\mathbf{1} \mathbf{b},{ }^{12} \mathbf{3} \mathbf{a},{ }^{11} \mathbf{3} \mathbf{b},{ }^{12}$ 3d, ${ }^{15 a} \mathbf{3 e},{ }^{15 b}$ and $\left[\mathrm{PdCl}_{2}(\mathrm{cod})\right]^{24}$ were prepared according to literature procedures. All other reagents were purchased and used without further purification. NMR spectra were recorded with a Varian Unity Inova 400 WB spectrometer $\left({ }^{1} \mathrm{H}\right.$ NMR, 399.716 M Hz; ${ }^{13} \mathrm{C} \mathrm{NMR,} \mathrm{100.6} \mathrm{M} \mathrm{Hz),} \mathrm{a} \mathrm{Varian} 300$ spectrometer $\left({ }^{1} \mathrm{H} N M R, 300.1 \mathrm{MHz} ;{ }^{13} \mathrm{C} N M R, 75.5 \mathrm{MHz}\right.$; ${ }^{31 \mathrm{P}} \mathrm{NMR}$, $121.5 \mathrm{MHz}$ ), or a Varian Gemini 200 spectrometer $\left({ }^{1} \mathrm{H} \mathrm{NMR}\right.$, $200.1 \mathrm{MHz} ;{ }^{13} \mathrm{C} \mathrm{NMR}, 50.3 \mathrm{MHz}$; ${ }^{31} \mathrm{P} \mathrm{NMR}, 81.0 \mathrm{MHz}$ ). Mikroanalyses were determined by either Dornis and Kolbe, Microanalytisches Laboratorium, Mülheim, Germany, or the Central Science Laboratory, University of Tasmania.

Synthesis of 1,3-Bis[(3,5-dimethylpyrazol-1-yl)methyl]benzene (2c). To a stirred suspension of finely cut potassium $(1.12 \mathrm{~g}, 29.9 \mathrm{mmol})$ in THF $(60 \mathrm{~mL})$ under an argon atmosphere was added 3,5-dimethylpyrazole ( $2.88 \mathrm{~g}, 29.9 \mathrm{mmol})$. The mixture was heated to reflux and maintained at this temperature until beads of molten potassium were no longer evident ( $\sim 3 \mathrm{~h}$ ). The solution was cooled to ambient temperature, and 2,6-bis(bromomethyl)benzene (3.59 g, $13.6 \mathrm{mmol}$ ) was added in one portion. The reaction mixture was allowed to stand at reflux overnight, quenched by addition of water $(0.1 \mathrm{~mL})$, and filtered and the solvent removed in vacuo. The product, 1,3$\left(3,5-\mathrm{Me}_{2} \mathrm{pzCH}_{2}\right)_{2} \mathrm{C}_{6} \mathrm{H}_{4}(\mathbf{2 c})$, was purified by distillation. Yield: $3.27 \mathrm{~g}$ (82\%). Mp: $68-71{ }^{\circ} \mathrm{C} .{ }^{1} \mathrm{H} N M R\left(\mathrm{CDCl}_{3}, 300 \mathrm{MHz}\right): \delta$ $7.24(\mathrm{t}, 3 \mathrm{~J}=7.7 \mathrm{~Hz}, 1 \mathrm{H}, \mathrm{Ar} \mathrm{H}), 6.94(\mathrm{~d}, 3 \mathrm{~J}=7.8 \mathrm{~Hz}, 2 \mathrm{H}, \mathrm{Ar}$ $\mathrm{H}), 6.76(\mathrm{~s}, 1 \mathrm{H}, \mathrm{Ar} \mathrm{H}$ ), 5.85 (s, 2H, H4-3,5-Me $\mathrm{pz}$ ), 5.18 (s, $\left.4 \mathrm{H}, \mathrm{CH}_{2}\right), 2.25\left(\mathrm{~s}, 6 \mathrm{H}, \mathrm{CH}_{3}\right), 2.12\left(\mathrm{~s}, 6 \mathrm{H}, \mathrm{CH}_{3}\right) .{ }^{13} \mathrm{C} \mathrm{NMR}\left(\mathrm{CDCl}_{3}\right.$, $75 \mathrm{MHz}): \delta 147.5,139.1,137.9,129.0,125.5,124.6,105.5,52.2$, 13.4, 11.0. Anal. Calcd for $\mathrm{C}_{18} \mathrm{H}_{22} \mathrm{~N}_{4}: \mathrm{C}, 73.44 ; \mathrm{H}, 7.53 ; \mathrm{N}$, 19.03. Found: C, 73.25; H, 7.39; N, 19.10 .

Synthesis of 1-(Chloropalladium)-2,6-bis[(3,5-dimethylpyrazol-1-yl)methyl]benzene (3c). A solution of $\mathrm{Pd}(\mathrm{OAC})_{2}$ $(0.10 \mathrm{~g}, 0.45 \mathrm{mmol})$ and $\mathbf{2 c}(0.15 \mathrm{~g}, 0.49 \mathrm{mmol})$ in acetic acid

(23) Dijkstra, H. P.; Kruithof, K.; Ronde, N.; Vogt, D.; van Klink, G. P. M.; van Koten, G. To be submitted for publication. SelRo nanofiltration membranes (MPF-60) were purchased from Koch Membrane Systems I nc., Düssel dorf, Germany; further product information may be found at http://www.kochmembrane.com. 47.

24) Drew, D.; Doyle, J. R.; Shaver, A. G. Inorg. Synth. 1972, 13, 
(10 mL) was heated to $120{ }^{\circ} \mathrm{C}$ and maintained at this temperature for $2 \mathrm{~h}$. The solvent was removed by rotary evaporation and the residue dissolved in $\mathrm{CH}_{2} \mathrm{Cl}_{2}(50 \mathrm{~mL})$. The resultant solution was washed with water $(3 \times 50 \mathrm{~mL})$. The solvent was removed by rotary evaporation and the product dissolved in acetone $(50 \mathrm{~mL})$ along with $\mathrm{LiCl}(0.24 \mathrm{~g})$. The mixture was stirred overnight and then centrifuged and the solution decanted to leave a tan solid. The product was washed with water $(20 \mathrm{~mL})$, acetone $(20 \mathrm{~mL})$, and $\mathrm{CH}_{2} \mathrm{Cl}_{2}(5 \mathrm{~mL})$ and dried in vacuo. Yield: $0.18 \mathrm{~g}(90 \%) .{ }^{1} \mathrm{H} \mathrm{NMR}\left(\mathrm{CDCl}_{3}, 300\right.$ $\mathrm{MHz}$ ): $\delta 6.39$ (s, 3H, Ar H), 5.82 (s, 2, H4 3,5-M ezpz), 5.65 (d, 3) $\left.=14.1 \mathrm{~Hz}, 2 \mathrm{H}, \mathrm{CH}_{2}\right), 4.90\left(\mathrm{~d}, 3 \mathrm{~J}=13.8 \mathrm{~Hz}, 2 \mathrm{H}, \mathrm{CH}_{2}\right), 2.65$ $\left(\mathrm{s}, 6 \mathrm{H}, \mathrm{CH}_{3}\right), 2.34\left(\mathrm{~s}, 6 \mathrm{H}, \mathrm{CH}_{3}\right) .{ }^{13} \mathrm{C} N M R\left(\mathrm{CDCl}_{3}, 75 \mathrm{MHz}\right): \delta$ 152.3, 145.8, 140.0, 137.0, 125.0, 124.2, 107.0, 54.3, 15.5, 11.7. Anal. Calcd for $\mathrm{C}_{18} \mathrm{H}_{21} \mathrm{ClN}_{4} \mathrm{Pd}$ : C, 49.67; $\mathrm{H}, 4.86 ; \mathrm{N}, 12.87$. Found: $\mathrm{C}, 49.78 ; \mathrm{H}, 4.92 ; \mathrm{N}, 12.80$.

Synthesis of 1-(Aquapalladium)-2,6-bis[(3,5-dimethylpyrazol-1-yl)methyl]benzene Tetrafluoroborate (1c). To a stirred suspension of $3 c$ ( $110 \mathrm{mg}, 0.24 \mathrm{mmol}$ ) in acetone $\left(10 \mathrm{~mL}\right.$ ) was added a solution of $\mathrm{AgBF}_{4}(47 \mathrm{mg}, 0.24 \mathrm{mmol})$ in water $(1.0 \mathrm{~mL})$. The solution was stirred in the absence of light for $10 \mathrm{~min}$ and then filtered through Celite. The solvent was removed in vacuo and the residue extracted with acetone (15 $\mathrm{mL})$. The solution was filtered, and a tan solid precipitated on addition of diethyl ether. Yield: $80 \mathrm{mg}(66 \%)$. ${ }^{1} \mathrm{H}$ NMR (acetone- $\mathrm{d}_{6}, 300 \mathrm{MHz}$ ): $\delta 7.20(\mathrm{~d}, 3 \mathrm{~J}=7.5 \mathrm{~Hz}, 2 \mathrm{H}, \mathrm{Ar} \mathrm{H}$ ), 7.03 (t, 3) $=7.5 \mathrm{~Hz}, 1 \mathrm{H}, \mathrm{Ar} \mathrm{H}), 6.08(\mathrm{~s}, 2 \mathrm{H}, \mathrm{H} 4$ 3,5-M e2pz), 5.68 (d, 3) $\left.=14.4 \mathrm{~Hz}, 2 \mathrm{H}, \mathrm{CH}_{2}\right), 5.40\left(\mathrm{~d}, 3 \mathrm{~J}=14.7 \mathrm{~Hz}, 2 \mathrm{H}, \mathrm{CH}_{2}\right), 2.50$ (s, 6H, $\left.\mathrm{CH}_{3}\right), 2.25$ (bs, 6H, $\mathrm{CH}_{3}$ ). ${ }^{13} \mathrm{C}$ NMR (acetone- $\mathrm{d}_{6}, 75$ $\mathrm{MHz}$ ): $\delta 150.5,142.6,136.8,126.1,125.1,106.8,53.7,12.9$, 10.7. Anal. Calcd for $\mathrm{C}_{18} \mathrm{H}_{23} \mathrm{BF}_{4} \mathrm{~N}_{4} \mathrm{OPd}$ : C, 42.84; $\mathrm{H}, 4.54 ; \mathrm{N}$, 11.10. Found: $\mathrm{C}, 42.71 ; \mathrm{H}, 4.65 ; \mathrm{N}, 10.98$.

Synthesis of 1-(Aquapalladium)-2,6-bis[(diphenylphosphino)methyl]benzene Tetrafluoroborate (1d). AgBF $(0.21 \mathrm{~g}, 1.1 \mathrm{mmol})$ dissolved in wet acetone $(1 \mathrm{~mL})$ was added to a solution of $\mathbf{3 d}(0.68 \mathrm{~g}, 1.1 \mathrm{mmol})$ in wet acetone $(15 \mathrm{~mL})$. This mixture was stirred in the absence of light at room temperature for $1 \mathrm{~h}$. Subsequently, the reaction mixture was filtered and the filtrate was reduced to a volume of $10 \mathrm{~mL}$. $\mathrm{Et}_{2} \mathrm{O}(10 \mathrm{~mL})$ was added, resulting in the precipitation of a white solid, which was collected, washed with $\mathrm{Et}_{2} \mathrm{O}(2 \times 10$ $\mathrm{mL}$ ), and dried in vacuo. Yield: $0.69 \mathrm{~g}(92 \%)$. ${ }^{1} \mathrm{H}$ NMR (acetone$\left.\mathrm{d}_{6}, 200 \mathrm{MHz}\right): \delta 7.93-7.83(\mathrm{~m}, 8 \mathrm{H}, \operatorname{Ar~H}), 7.72-7.63(\mathrm{~m}, 12 \mathrm{H}$, Ar H), 7.28-7.17 (3H, Ar H), 4.24 (pseudot, ${ }^{2} \mathrm{~J}_{\mathrm{P}, \mathrm{H}}$ and ${ }^{4} \mathrm{~J} \mathrm{P}, \mathrm{H}=$ $4.8 \mathrm{~Hz}, 4 \mathrm{H}, \mathrm{CH}_{2}$ ). ${ }^{31} \mathrm{P} \mathrm{NMR}$ (acetone- $\mathrm{d}_{6}$ ): $\delta 47.9$.

Synthesis of 1-(Aquapalladium)-2,6-bis[(phenylsulfido)methyl]benzene Tetrafluoroborate (1e). AgBF $_{4}(0.21$ $\mathrm{g}, 1.1 \mathrm{mmol})$ in wet acetone ( $1 \mathrm{~mL})$ was added to a solution of $3 e(0.51 \mathrm{~g}, 1.1 \mathrm{mmol})$ in wet acetone $(15 \mathrm{~mL})$. This mixture was stirred in the absence of light at room temperature for 1 h. Subsequently, the reaction mixture was filtered and the filtrate was reduced to a volume of $10 \mathrm{~mL}$. $\mathrm{Et}_{2} \mathrm{O}(10 \mathrm{~mL})$ was added, resulting in the precipitation of a light yellow solid, which was collected, washed with $\mathrm{Et}_{2} \mathrm{O}(2 \times 10 \mathrm{~mL})$, and dried in vacuo. Yield: $0.55 \mathrm{~g}(94 \%) .{ }^{1} \mathrm{H}$ NMR (acetone- $\mathrm{d}_{6}, 200$ $\mathrm{MHz}): \delta 7.90-7.96(\mathrm{~m}, 4 \mathrm{H}, \mathrm{Ar} \mathrm{H}), 7.52-7.59(\mathrm{~m}, 6 \mathrm{H}, \mathrm{Ar} \mathrm{H})$, 7.10-7.13 (m, 3H, Ar H), 4.91 (bs, 4H, $\mathrm{CH}_{2}$ ).

Synthesis of 3,5-Dimethyliodobenzene (4). A solution of $\mathrm{NaNO}_{2}(30.0 \mathrm{~g}, 435 \mathrm{mmol})$ in $\mathrm{H}_{2} \mathrm{O}(100 \mathrm{~mL})$ was added dropwise over a period of $15 \mathrm{~min}$ to a solution of 3,5dimethylaniline $(50.0 \mathrm{~g}, 413 \mathrm{mmol})$ in aqueous $\mathrm{H}_{2} \mathrm{SO}_{4}(650 \mathrm{~mL}$, $4.5 \mathrm{M})$ at $-10^{\circ} \mathrm{C}$. The resulting reaction mixture was stirred at $-10^{\circ} \mathrm{C}$ for an additional $15 \mathrm{~min}$, after which a solution of $\mathrm{KI}(80 \mathrm{~g}, 482 \mathrm{mmol})$ in $\mathrm{H}_{2} \mathrm{O}(100 \mathrm{~mL})$ was slowly added over a period of $5 \mathrm{~min}$, while the temperature was maintained at $-10^{\circ} \mathrm{C}$. The reaction mixture was warmed and stirred for $2 \mathrm{~h}$ each at 0,20 , and $90^{\circ} \mathrm{C}$. The resulting dark brown reaction mixture was cooled to room temperature and subsequently extracted with $\mathrm{Et}_{2} \mathrm{O}(3 \times 200 \mathrm{~mL})$. The combined organic extracts were washed successively with aqueous $\mathrm{Na}_{2} \mathrm{SO}_{3}(100$ $\mathrm{mL}, 1 \mathrm{M})$, aqueous $\mathrm{NaOH}(100 \mathrm{~mL}, 4 \mathrm{M})$, and brine $(100 \mathrm{~mL})$ and were then dried with $\mathrm{K}_{2} \mathrm{CO}_{3}$. After filtration, the filtrate was reduced in vacuo to leave a brown oily residue. This residue was flame-distilled from solid $\mathrm{KOH}(10 \mathrm{~g})$ to afford $\mathrm{C}_{6} \mathrm{H}_{3} \mathrm{l}(\mathrm{Me})_{2}-3,5$ (4) as a light orange oil. Yield: $67.1 \mathrm{~g}(70 \%)$. ${ }^{1} \mathrm{H}$ NMR $\left(\mathrm{C}_{6} \mathrm{D}_{6}, 200 \mathrm{MHz}\right): \delta 7.18(\mathrm{~s}, 2 \mathrm{H}, \mathrm{Ar} \mathrm{H}), 6.57(\mathrm{~s}, 1 \mathrm{H}$, $\operatorname{Ar~H}), 1.90\left(\mathrm{~s}, 6 \mathrm{H}, \mathrm{CH}_{3}\right) .{ }^{13} \mathrm{C} N M R\left(\mathrm{C}_{6} \mathrm{D}_{6}, 50 \mathrm{MHz}\right): \delta 140.0$, 135.4, 129.6, 94.9, 21.0.

Synthesis of 3,5-Bis(bromomethyl)iodobenzene (5). $\mathrm{C}_{6} \mathrm{H}_{3} \mathrm{l} \mathrm{Me}-3,5$ (4; $55.0 \mathrm{~g}, 237 \mathrm{mmol}$ ), N-bromosuccinimide (95.0 g, $534 \mathrm{mmol}$ ), and AIBN (azobis(isobutyronitrile); $2.63 \mathrm{~g}, 16$ $\mathrm{mmol}$ ) were mixed in methyl acetate $(400 \mathrm{~mL})$. This mixture was photolytically heated to reflux by irradiation of the flask with a $100 \mathrm{~W}$ IR bulb for $12 \mathrm{~h}$ (no additional heating source was used). The reaction mixture was then cooled to room temperature, followed by evaporation of the volatiles. This resulted in the formation of a solid residue, which was washed with cold hexanes $\left(0{ }^{\circ} \mathrm{C}, 2 \times 200 \mathrm{~mL}\right)$ and subsequently extracted with boiling hexanes $(4 \times 400 \mathrm{~mL})$. The combined hexanes extract was heated to reflux to redissolve all solids, and the solution was cool ed to room temperature over a period of $18 \mathrm{~h}$. Crystals of pure $\mathbf{5}$ that had formed during this time were collected by filtration, washed with cold hexanes $\left(0^{\circ} \mathrm{C}\right.$, $2 \times 200 \mathrm{~mL}$ ), and dried in vacuo. Yield: $43.5 \mathrm{~g}(47 \%) . \mathrm{Mp}$ : 110-113 ${ }^{\circ} \mathrm{C}$ (lit. ${ }^{16} \mathrm{mp} 112-114{ }^{\circ} \mathrm{C}$ ). ${ }^{1} \mathrm{H} \mathrm{NMR}\left(\mathrm{CDCl}_{3}, 200\right.$ $\mathrm{MHz}): \delta 7.67$ (s, 2H, Ar H), 7.38 (s, 1H, Ar H), 4.38 (s, 4H, $\left.\mathrm{CH}_{2}\right) .{ }^{13} \mathrm{C} \mathrm{NMR}\left(\mathrm{CDCl}_{3}, 50 \mathrm{MHz}\right): \delta 140.3,137.8,129.0,94.4$ 31.4.

Synthesis of 3,5-Bis(methoxymethyl)iodobenzene (6). Synthesis as described by Duchêne and Vögtle ${ }^{16}$ using 5 (75.9 g, $194 \mathrm{mmol}$ ) as the starting material. Yield: $54.0 \mathrm{~g}(95 \%) .{ }^{1} \mathrm{H}$ NMR $\left(\mathrm{CDCl}_{3}, 200 \mathrm{MHz}\right): \delta 7.58(\mathrm{~s}, 2 \mathrm{H}, \mathrm{Ar} \mathrm{H}), 7.22(\mathrm{~s}, 1 \mathrm{H}, \mathrm{Ar}$ $\mathrm{H}), 4.35$ (s, 4H, $\left.\mathrm{CH}_{2}\right), 3.35$ (s, 6H, OMe); ${ }^{13} \mathrm{C} \mathrm{NMR}\left(\mathrm{CDCl}_{3}, 50\right.$ $\mathrm{MHz}): \delta 140.7,135.6,125.8,94.5,73.6,58.4$.

Synthesis of Bis[3,5-bis(methoxymethyl)phenyl]acetylene (7). Solid $\left[\mathrm{PdCl}_{2}\left(\mathrm{PPh}_{3}\right)_{2}\right](2.60 \mathrm{~g}, 3.7 \mathrm{mmol})$ and $\mathrm{Cul}(0.35$ $\mathrm{g}, 1.85 \mathrm{mmol}$ ) were added to a stirring solution of 3,5-bis(methoxymethyl)iodobenzene (6; $54.0 \mathrm{~g}, 185 \mathrm{mmol}$ ) in $\mathrm{Et}_{2} \mathrm{NH}$ $(500 \mathrm{~mL})$ at room temperature in a $1 \mathrm{~L}$ round-bottomed Schlenk tube. After stirring of the reagents, a slow stream of acetylene was passed through the stirred solution for $16 \mathrm{~h}$ at room temperature. The col or of the reaction mixture gradually turned to dark red and after $16 \mathrm{~h}$ a two-phase system had formed. After in vacuo evaporation of the volatiles, the residue was extracted with hexanes $(2 \times 200 \mathrm{~mL})$ and the combined organic extracts were stored at $-25^{\circ} \mathrm{C}$ for $24 \mathrm{~h}$. The precipitated white solid which formed during this time was filtered off, washed with cold hexanes $\left(-25^{\circ} \mathrm{C}, 100 \mathrm{~mL}\right)$ and dried in vacuo to afford 7 as a white solid. Yield: $29.5 \mathrm{~g}$ (90\%). Mp: $37-39^{\circ} \mathrm{C}$ (lit. $\left.{ }^{16} 38-41^{\circ} \mathrm{C}\right) .{ }^{1} \mathrm{H} N M R\left(\mathrm{CDCl}_{3}, 200 \mathrm{MHz}\right): \delta 7.42$ (s, 4H, Ar H), 7.28 (s, 2H, Ar H), 4.44 (s, 8H, $\mathrm{CH}_{2}$ ), 3.39 (s, $12 \mathrm{H}, \mathrm{OMe}) .{ }^{13} \mathrm{C} \mathrm{NMR}\left(\mathrm{CDCl}_{3}, 50 \mathrm{MHz}\right): \delta 136.6,129.9,126.7$, $123.4,89.3,74.1,58.3$.

Synthesis of Hexakis[3,5-bis(methoxymethyl)phenyl]benzene (8). Synthesis was as described by Duchêne and Vögtle ${ }^{16}$ using 7 (27.3 g, $\left.77.0 \mathrm{mmol}\right)$ and [ $\left.\mathrm{PdCl}_{2}(\mathrm{NCPh})_{2}\right]$ (12.1 $\mathrm{g}, 47.3 \mathrm{mmol})$ in benzene $(150 \mathrm{~mL})$. The workup was performed as follows: after evaporation of the vol atiles, the solid residue was extracted with boiling hexanes $(3 \times 250 \mathrm{~mL})$. The combined hexane extract was cooled to room temperature over a period of $20 \mathrm{~h}$ after which pure $\mathbf{8}$ had separated from the solution as colorless crystals, which were collected by filtration, washed with hexanes $(2 \times 100 \mathrm{~mL})$ and dried in vacuo. Yield: $16.4 \mathrm{~g}(60 \%)$. ${ }^{1 \mathrm{H}} \mathrm{NMR}\left(\mathrm{CDCl}_{3}, 200 \mathrm{MHz}\right): \delta 6.70$ (s, $12 \mathrm{H}, \mathrm{Ar}$ $\mathrm{H}), 6.61$ (s, 6H, $\mathrm{Ar} \mathrm{H}), 3.99$ (s, 24H, $\left.\mathrm{CH}_{2}\right), 2.83$ (s, 36H, OMe). ${ }^{13} \mathrm{C} \mathrm{NMR}\left(\mathrm{CDCl}_{3}, 50 \mathrm{MHz}\right): \delta 140.4,139.6,136.6,130.0,124.3$, $73.8,56.8$

Synthesis of Hexakis[3,5-bis(bromomethyl)phenyl]benzene (9). Synthesis was as described by Duchêne and Vögtle ${ }^{16}$ using 8 (16.4 g, $\left.15.4 \mathrm{mmol}\right), \mathrm{BF}_{3} \cdot \mathrm{Et}_{2} \mathrm{O}(80 \mathrm{~mL}, 635$ $\mathrm{mmol}$ ), and acetyl bromide (55 mL, $740 \mathrm{mmol}$ ) in $\mathrm{CH}_{2} \mathrm{Cl}_{2}$ (1200 $\mathrm{mL})$. The workup was performed as follows: the reaction 
mixture was cooled with an ice bath and aqueous $\mathrm{Na}_{2} \mathrm{CO}_{3}$ $(25 \%, 400 \mathrm{~mL})$ was slowly added. After complete addition the mixture was stirred for $15 \mathrm{~min}$ at room temperature. The $\mathrm{CH}_{2-}$ $\mathrm{Cl}_{2}$ layer was then collected, dried with $\mathrm{MgSO}_{4}$, filtered, and concentrated to ca. $300 \mathrm{~mL}$. Hexane was slowly added to the resulting solution, resulting in the separation of pure hexasubstituted benzene $\mathbf{9}$ as white crystals. The crystals were collected by filtration, washed with hexanes $(2 \times 100 \mathrm{~mL})$, and dried in vacuo. Yield: $23.5 \mathrm{~g}(93 \%)$. ${ }^{1} \mathrm{H}$ NMR $\left(\mathrm{CDCl}_{3}, 200\right.$ $\mathrm{MHz}): \delta 6.90(\mathrm{~s}, 6 \mathrm{H}, \mathrm{Ar} \mathrm{H}), 6.83(\mathrm{~s}, 12 \mathrm{H}, \mathrm{Ar} \mathrm{H}), 4.17(\mathrm{~s}, 24 \mathrm{H}$, $\left.\mathrm{CH}_{2}\right) .{ }^{13} \mathrm{C} \mathrm{NMR}\left(\mathrm{CDCl}_{3}, 50 \mathrm{MHz}\right): \delta 140.4,139.4,137.6,131.9$, 127.1, 32.9.

Synthesis of Hexakis\{3,5-bis[(dimethylamino)methyl]phenyl $\}$ benzene (10). Neat $\mathrm{HNMe}_{2}(10 \mathrm{~mL}, 150 \mathrm{mmol})$ was added in one portion to a solution of 9 (1.65 g, $1.00 \mathrm{mmol})$ in $\mathrm{CH}_{2} \mathrm{Cl}_{2}(100 \mathrm{~mL})$ at $0{ }^{\circ} \mathrm{C}$. The reaction mixture was warmed to room temperature over a period of $1 \mathrm{~h}$ and was stirred for an additional $3 \mathrm{~h}$. Aqueous $\mathrm{NaOH}(40 \mathrm{~mL}, 4 \mathrm{M}, 160 \mathrm{mmol})$ was then added, the $\mathrm{CH}_{2} \mathrm{Cl}_{2}$ layer was collected, and the water layer was extracted with $\mathrm{Et}_{2} \mathrm{O}(4 \times 50 \mathrm{~mL})$. The combined organic fraction was washed with saturated aqueous $\mathrm{NaCl}$ (50 $\mathrm{mL}$ ), dried with $\mathrm{MgSO}_{4}$ and filtered. Evaporation of the filtrate in vacuo afforded crude $\mathbf{1 0}$ as a pale yellow solid, mp 51-54 ${ }^{\circ} \mathrm{C}$. Pure $\mathbf{1 0}$ was obtained by recrystallization of the corresponding $\mathrm{HBF}_{4}$ salt, $\left[\mathrm{C}_{6}\left\{\mathrm{C}_{6} \mathrm{H}_{3}\left(\mathrm{CH}_{2} \mathrm{~N}(\mathrm{H}) \mathrm{Me}_{2}\right)_{2}-3,5\right\}_{6}\right]\left(\mathrm{BF}_{4}\right)_{12}\left(\mathbf{1 0}^{\prime}\right)$, which was prepared by addition of aqueous $\mathrm{HBF}_{4}$ (35\%, excess) to a solution of crude $\mathbf{1 0}$ in $\mathrm{H}_{2} \mathrm{O}(20 \mathrm{~mL})$. Addition of $\mathrm{MeOH}$ $\left(150 \mathrm{~mL}\right.$ ) followed by warming of the mixture to ca. $60{ }^{\circ} \mathrm{C}$ afforded a clear solution, from which upon cooling to room temperature analytically pure white crystals ( $\mathrm{mp} 161-163^{\circ} \mathrm{C}$ ) of the dodecakis(tetrafluoroborate) salt $\mathbf{1 0}$ separated. The crystals were filtered off, washed with $\mathrm{MeOH}(2 \times 30 \mathrm{~mL})$ and dried in vacuo. Dissolution of crystalline $\mathbf{1 0}$ in $\mathrm{H}_{2} \mathrm{O}$ afforded a clear solution which was neutralized with aqueous $\mathrm{NaOH}$ ( $2 \mathrm{M}$, excess), followed by extraction of the desired product $\mathbf{1 0}$ with $\mathrm{CH}_{2} \mathrm{Cl}_{2}(3 \times 60 \mathrm{~mL})$. The combined $\mathrm{CH}_{2} \mathrm{Cl}_{2}$ extracts were dried with $\mathrm{MgSO}_{4}$, filtered, and evaporated in vacuo to afford pure 10. Yield: $0.96 \mathrm{~g}(79 \%)$.

10: ${ }^{1} \mathrm{H} N M R\left(\mathrm{C}_{6} \mathrm{D}_{6}, 200 \mathrm{MHz}\right) \delta 6.97(\mathrm{~s}, 6 \mathrm{H}, \mathrm{Ar} \mathrm{H}), 6.94(\mathrm{~s}$, $12 \mathrm{H}, \mathrm{Ar} \mathrm{H}), 3.10\left(\mathrm{~s}, 24 \mathrm{H}, \mathrm{CH}_{2}\right), 1.98(\mathrm{~s}, 72 \mathrm{H}, \mathrm{Me}) ;{ }^{13} \mathrm{C} N M R$ $\left(\mathrm{C}_{6} \mathrm{D}_{6}, 50 \mathrm{MHz}\right): \delta 141.3,140.5,137.9,131.5,126.9,64.5,45.4$.

10: ${ }^{1} \mathrm{H}$ NMR $\left(\mathrm{D}_{2} \mathrm{O}, 300 \mathrm{MHz}\right) \delta 7.37(\mathrm{~s}, 12 \mathrm{H}, \mathrm{Ar} \mathrm{H}), 7.17(\mathrm{~s}$, $6 \mathrm{H}, \mathrm{Ar} \mathrm{H}), 4.05\left(\mathrm{~s}, 24 \mathrm{H}, \mathrm{CH}_{2}\right), 2.46\left(\mathrm{~s}, 72 \mathrm{H}, \mathrm{HNMe}_{2}\right) ;{ }^{13} \mathrm{C} \mathrm{NMR}$ $\left(\mathrm{D}_{2} \mathrm{O}, 75 \mathrm{MHz}\right) \delta 141.8,138.7,134.9,130.9,130.6,59.1,41.9$. Anal. Calcd for $\mathrm{C}_{78} \mathrm{H}_{126} \mathrm{~B}_{12} \mathrm{~F}_{48} \mathrm{~N}_{12}$ (10): C, 41.21; H, 5.59; N, 7.39. Found: $\mathrm{C}, 41.19 ; \mathrm{H}, 5.55 ; \mathrm{N}, 7.35$.

Synthesis of Hexakis 3 3,5-bis[(phenylsulfido)methyl] phenyl \} benzene (11). Thiophenol $(2.5 \mathrm{~mL}, 24.4 \mathrm{mmol})$ was added in one portion to a solution of $9(1.65 \mathrm{~g}, 1.00 \mathrm{mmol})$ in degassed DMF $(50 \mathrm{~mL})$ under nitrogen at room temperature. Solid $\mathrm{K}_{2} \mathrm{CO}_{3}(7.9 \mathrm{~g}, 50 \mathrm{mmol})$ was added and the resulting mixture was stirred for $48 \mathrm{~h}$ at $50{ }^{\circ} \mathrm{C}$. The volatiles were evaporated in vacuo and the residue was extracted with $\mathrm{CH}_{2-}$ $\mathrm{Cl}_{2}(3 \times 50 \mathrm{~mL})$. The combined organic fraction was washed with brine $(50 \mathrm{~mL})$, dried with $\mathrm{MgSO}_{4}$ and filtered. Evaporation of the filtrate in vacuo afforded crude $\mathbf{1 1}$ as a pale yellow waxy solid. The hexasubstituted benzene $\mathbf{1 1}$ was purified by slow diffusion of pentane into a concentrated solution of crude 11 in $\mathrm{CH}_{2} \mathrm{Cl}_{2}$. This resulted in the formation of off-white crystals, which were collected by filtration, washed with pentane $(50 \mathrm{~mL})$, and dried in vacuo. Yield: $1.66 \mathrm{~g}(83 \%) .{ }^{1} \mathrm{H}$ NMR $\left(\mathrm{CDCl}_{3}, 300 \mathrm{MHz}\right): \delta 7.22-7.10(\mathrm{~m}, 60 \mathrm{H}, \mathrm{Ar} \mathrm{H}), 6.96(\mathrm{~s}$, $12 \mathrm{H}, \mathrm{Ar} \mathrm{H}), 6.64(\mathrm{~s}, 6 \mathrm{H}, \mathrm{Ar} \mathrm{H}), 3.67\left(\mathrm{~s}, 24 \mathrm{H}, \mathrm{CH}_{2}\right) .{ }^{13} \mathrm{C} N M R$ $\left(\mathrm{CDCl}_{3}, 75 \mathrm{MHz}\right): \delta 146.1,140.9,139.8,137.2,136.0,130.8$, 128.8, 126.9, 125.9, 38.4. MALDI-TOF-MS: m/z 1999.78 ([M] ${ }^{+}$, calcd 2000.97), 1891.49 ([M - SPh $]^{+}$, calcd 1891.80), 1781.47 $\left([\mathrm{M}-2 \mathrm{SPh}]^{+}\right.$, calcd 1782.63). Anal. Calcd for $\mathrm{C}_{126} \mathrm{H}_{102} \mathrm{~S}_{12}: \mathrm{C}$, 75.63; H, 5.14; S, 19.23. Found: C, 75.85; H, 5.29; S, 19.23 .

Synthesis of Hexakis\{3,5-bis[(diphenylphosphino)methyl]phenyl \} benzene (12). n-BuLi (3.62 mL, $5.79 \mathrm{mmol}$ ) was added to $\mathrm{HPPh}_{2} \cdot \mathrm{BH}_{3}(1.08 \mathrm{~g}, 5.40 \mathrm{mmol})$ in THF $(30 \mathrm{~mL})$ at $-70{ }^{\circ} \mathrm{C}$. The temperature was allowed to rise to room temperature, and stirring was continued for $2 \mathrm{~h}$. Next, this solution was added to a solution of $9(0.50 \mathrm{~g}, 0.30 \mathrm{mmol})$ in THF $(30 \mathrm{~mL})$ at $-40{ }^{\circ} \mathrm{C}$. The temperature was allowed to rise to room temperature, and the mixture was stirred for another $18 \mathrm{~h}$. All volatiles were evaporated, $\mathrm{CH}_{2} \mathrm{Cl}_{2}(75 \mathrm{~mL})$ was added, and this mixture was washed with $\mathrm{H}_{2} \mathrm{O}(3 \times 50 \mathrm{~mL})$ and dried over $\mathrm{MgSO}_{4}$. The $\mathrm{CH}_{2} \mathrm{Cl}_{2}$ was evaporated, and the white solid was washed with hot EtOH $(2 \times 50 \mathrm{~mL})$ and hexanes $(3 \times 50$ $\mathrm{mL}$ ) and dried in vacuo to give $\mathbf{1 2} \cdot 12 \mathrm{BH}_{3}$ as a white air-stable powder. Yield: $0.87 \mathrm{~g}(94 \%)$. ${ }^{1} \mathrm{H}$ NMR (toluene-d $8,300 \mathrm{MHz}$ ): $\delta 8.17$ (pseudot, ${ }^{3}{ }_{\mathrm{H}, \mathrm{H}}$ and ${ }^{3} \mathrm{~S} \mathrm{P}, \mathrm{H}=9 \mathrm{~Hz}, 24 \mathrm{H}, \mathrm{O}-\mathrm{H} \mathrm{Ar}-\mathrm{P}$ ), 7.87 (pseudot, ${ }^{3} \mathrm{H}_{\mathrm{H}, \mathrm{H}}$ and $^{3} \mathrm{~J} \mathrm{P}, \mathrm{H}=9 \mathrm{~Hz}, 24 \mathrm{H}, \mathrm{O}-\mathrm{H} \mathrm{Ar}-\mathrm{P}$ ), 7.42-7.15 $(\mathrm{m}, 72 \mathrm{H}, \mathrm{Ar} \mathrm{H}), 6.55(\mathrm{~s}, 12 \mathrm{H}, \mathrm{Ar} \mathrm{H}), 6.21(\mathrm{~s}, 6 \mathrm{H}, \operatorname{Ar~H}), 4.07$ and 3.39 (pseudot, $A B X{ }^{2}{ }^{2}{ }_{H, H}$ and ${ }^{2} \mathrm{P}, \mathrm{H}=12.5 \mathrm{~Hz}, 24 \mathrm{H}, \mathrm{CH}_{2}$ ), 1.61 (br s, 36H, $\left.\mathrm{BH}_{3}\right) .{ }^{13} \mathrm{C} \mathrm{NMR}\left(\mathrm{CDCl}_{3}, 75 \mathrm{MHz}^{2}: \delta 32.38(\mathrm{~d}\right.$, IJ $P, C=34.0 \mathrm{~Hz}$ ), 128.4-140.5 (9 different $\mathrm{Ar}-\mathrm{C}$ ). ${ }^{31} \mathrm{P}$ NMR $\left(\mathrm{CDCl}_{3}, 121 \mathrm{MHz}\right): \delta$ 17.78. Anal. Calcd for $\mathrm{C}_{198} \mathrm{H}_{198} \mathrm{P}_{12} \mathrm{~B}_{12}: \mathrm{C}$, 77.23; H, 6.48; $\mathrm{P}, 12.07$; $\mathrm{B}, 4.21$. Found: $\mathrm{C}$, 77.17; H, 6.64; $\mathrm{P}$, 11.95; B, 4.16.

Removal of $\mathbf{B H}_{3}$ from 12.12B $\mathbf{H}_{3} \cdot \mathrm{HBF}_{4} \cdot \mathrm{OEt}_{2}(1.98 \mathrm{~mL}$, $6.60 \mathrm{mmol}$ ) was added dropwise to a solution of $12 \cdot 12 \mathrm{BH}_{3}(0.31$ $\mathrm{g}, 0.10 \mathrm{mmol})$ in $\mathrm{CH}_{2} \mathrm{Cl}_{2}(25 \mathrm{~mL})$ at $0-5{ }^{\circ} \mathrm{C}$. The temperature was allowed to rise to room temperature, and stirring was continued for $2 \mathrm{~h}$. Next, a saturated $\mathrm{NaHCO}_{3}(\mathrm{aq})$ solution (50 $\mathrm{mL}$ ) was added dropwise at $0{ }^{\circ} \mathrm{C}$, resulting in considerable gas evolution. After complete addition the reaction mixture was stirred for $1 \mathrm{~h}$ at room temperature. The organic layer was collected, the water layer was washed with $\mathrm{CH}_{2} \mathrm{Cl}_{2}(2 \times 25$ $\mathrm{mL})$, and the combined organic layer was dried $\left(\mathrm{MgSO}_{4}\right)$. After evaporation of all volatiles $\mathbf{1 2}$ was obtained as a white solid in quantitative yield. This product was used without further purification. ${ }^{1} \mathrm{H} N \mathrm{NR}\left(\mathrm{C}_{6} \mathrm{D}_{6}, 200 \mathrm{MHz}\right): \delta 7.29-6.94(\mathrm{~m}, 72 \mathrm{H})$, $6.13(\mathrm{~s}, 6 \mathrm{H}), 3.21$ (br s, 24H ). ${ }^{13} \mathrm{C}$ NMR $\left(\mathrm{C}_{6} \mathrm{D}_{6}, 50 \mathrm{MHz}\right): \delta 139.6$ $\left(d,{ }^{1} \mathrm{~J}, C=11.3 \mathrm{~Hz}\right), 136.4,133.2\left(\mathrm{~d},{ }^{2} \mathrm{~J} P, C=12.1 \mathrm{~Hz}\right), 128$ 4, 128.3, 128.2, 127.9, 127.6, 36.3. ${ }^{31} \mathrm{P}$ NMR $\left(\mathrm{C}_{6} \mathrm{D}_{6}, 54 \mathrm{MHz}\right): \delta$ $-7.95(\mathrm{~s})$

Synthesis of Hexakis\{3,5-bis[(pyrazol-1-yl)methyl]phenyl $\}$ benzene (13). To a stirred suspension of finely cut potassium $(0.16 \mathrm{~g}, 4.18 \mathrm{mmol})$ in dry THF $(40 \mathrm{~mL})$ was added pyrazole $(0.30 \mathrm{~g}, 4.36 \mathrm{mmol})$. The mixture was heated to reflux and maintained at this temperature until the beads of molten potassium were no longer evident $( \pm 1 \mathrm{~h})$. The resulting white suspension was cooled to ambient temperature, and $\mathbf{9}(0.50 \mathrm{~g}$, $0.30 \mathrm{mmol}$ ) was added in one portion. The reaction mixture was heated at reflux for $15 \mathrm{~h}$ and then quenched by addition of $\mathrm{H}_{2} \mathrm{O}(0.1 \mathrm{~mL})$ and filtered; the solvent was removed in vacuo. The product was dissolved in $\mathrm{CH}_{2} \mathrm{Cl}_{2}(20 \mathrm{~mL})$, the mixture was filtered, and the filtrate was reduced to $\sim 1 \mathrm{~mL}$. The product precipitated as a white solid on addition of $\mathrm{Et}_{2} \mathrm{O}$ and was finally crystallized from $\mathrm{CH}_{2} \mathrm{Cl}_{2} / \mathrm{Et}_{2} \mathrm{O}$, giving 13 as small white crystals. Yield: $0.40 \mathrm{~g}(89 \%) .{ }^{1} \mathrm{H}$ NMR $\left(\mathrm{CDCl}_{3}, 300 \mathrm{MHz}\right): \delta$ $7.46(\mathrm{~d}, 12 \mathrm{H}, 3 \mathrm{~J}=1.80 \mathrm{~Hz}, \mathrm{pz}-\mathrm{H} 3), 6.80(\mathrm{~d}, 12 \mathrm{H}, 3 \mathrm{~J}=2.10$, pz-H 5), 6.65 (s, 6H, Ar H), 6.38 (s, 12H, Ar H), 6.15 (t, 12H, $\mathrm{pz}-\mathrm{H} 4), 4.84\left(\mathrm{~s}, 24 \mathrm{H}, \mathrm{CH}_{2}\right) .{ }^{13} \mathrm{C} \mathrm{NMR}\left(\mathrm{CDCl}_{3}, 75 \mathrm{MHz}\right): \delta$ $140.46,139.28,135.97,130.05,128.95,125.20,105.78,55.09$. Anal. Calcd for $\mathrm{C}_{90} \mathrm{H}_{78} \mathrm{~N}_{24}$ : C, 72.27; $\mathrm{H}, 5.26 ; \mathrm{N}, 22.47$. Found: C, 72.35; H, 5.28; N, 22.36.

Synthesis of Hexakis\{4-(chloropalladium)-3,5-bis[(phenylsulfido)methyl]phenyl $\}$ benzene (14). A solution of $\left[\mathrm{Pd}(\mathrm{NCMe})_{4}\right]\left(\mathrm{BF}_{4}\right)_{2}(1.41 \mathrm{~g}, 3.2 \mathrm{mmol})$ in degassed $\mathrm{MeCN}$ $(10 \mathrm{~mL})$ was added over a period of $2 \mathrm{~min}$ to a solution of the hexasubstituted benzene $\mathrm{C}_{6}\left\{\mathrm{C}_{6} \mathrm{H}_{3}\left(\mathrm{CH}_{2} \mathrm{SPh}\right)_{2}-3,5\right\}_{6}$ (11; $1.0 \mathrm{~g}$, $0.50 \mathrm{mmol}$ ) in degassed $\mathrm{MeCN}(40 \mathrm{~mL})$. A red-brown solution formed immediately and was heated at reflux for $5 \mathrm{~h}$. The resulting solution was evaporated to $\sim 15 \mathrm{~mL}$, and $\mathrm{Et}_{2} \mathrm{O}(50$ $\mathrm{mL})$ was slowly added. This resulted in the precipitation of $\left[\mathrm{C}_{6}\left(\{\mathrm{Pd}(\mathrm{NCMe})\} \mathrm{C}_{6} \mathrm{H}_{2}\left(\mathrm{CH}_{2} \mathrm{SPh}\right)_{2}-3,5\right)_{6}\right]\left(\mathrm{BF}_{4}\right)_{6}$ as a pale yellow solid, which was collected, washed with $\mathrm{Et}_{2} \mathrm{O}$, and dried in vacuo. Yield: $1.56 \mathrm{~g}$. Subsequently, this solid was dissolved in $\mathrm{MeCN}(80 \mathrm{~mL})$, and $\mathrm{LiCl}$ (large excess) was added in one 
portion. This resulted in a suspension which was stirred for an additional $15 \mathrm{~h}$. Subsequently, the solid material was filtered off and washed with $\mathrm{H}_{2} \mathrm{O}(100 \mathrm{~mL})$ and $\mathrm{Et}_{2} \mathrm{O}(2 \times 100$ $\mathrm{mL}$ ), giving a yellow solid. This solid was dissolved in DMSO (80 mL), and THF (140 mL) was added, resulting in a white precipitate. This procedure was repeated three times, and the solid was collected and dried in vacuo, affording 14 as a light yellow solid. Yield: $1.28 \mathrm{~g}(90 \%)$. Yellow crystals suitable for $\mathrm{X}$-ray analysis were obtained by suspension of $\mathbf{1 4}$ in toluene and addition of $\mathrm{CH}_{2} \mathrm{Cl}_{2}$ until all solids were dissolved, followed by slow evaporation of the solvent in air. ${ }^{2 \mathrm{~h}}{ }^{1 \mathrm{H}} \mathrm{NMR}$ (DMSO$\left.\mathrm{d}_{6}, 200 \mathrm{MHz}\right): \delta 7.60-7.56(\mathrm{~m}, 24 \mathrm{H}, \mathrm{Ar} \mathrm{H}), 7.44-7.31(\mathrm{~m}, 36 \mathrm{H}$, $\operatorname{Ar~H}), 6.33$ (s, $12 \mathrm{H}, \mathrm{Ar} \mathrm{H}), 4.20$ (br s, $\left.24 \mathrm{H}, \mathrm{CH}_{2}\right) .{ }^{13} \mathrm{C} N M R$ (DMSO- $\mathrm{d}_{6}, 50 \mathrm{MHz}$ ): $\delta 161.06,148.22,139.38,136.80,132.09$, 130.60, 130.28, 130.20, 125.65, 49.76. MALDI-TOF-MS: m/z $2811.52\left([\mathrm{M}-\mathrm{Cl}]^{+}\right.$, calcd. 2810.71). Anal. Calcd for $\mathrm{C}_{126} \mathrm{H}_{96}$ $\mathrm{Cl}_{6} \mathrm{Pd}_{6} \mathrm{~S}_{12}$ : C, 53.26; $\mathrm{H}, 3.48 ; \mathrm{S}, 13.37$. Found: $\mathrm{C}, 53.17 ; \mathrm{H}$, 3.40; S, 13.52.

Synthesis of Hexakis 4-(chloropalladium)-3,5-bis[(diphenylphosphino)methyl]phenyl $\}$ benzene (15). $[\mathrm{Pd}(\mathrm{N}$ $\left.\mathrm{CMe})_{4}\right]\left(\mathrm{BF}_{4}\right)_{2}(0.16 \mathrm{~g}, 0.38 \mathrm{mmol})$ dissolved in degassed $\mathrm{MeCN}$ $(5 \mathrm{~mL})$ was added to a suspension of $\mathbf{1 2}(0.18 \mathrm{~g}, 63 \mathrm{mmol})$ in degassed $\mathrm{MeCN}$ ( $15 \mathrm{~mL}$ ), immediately resulting in a yellow solution. This mixture was heated at reflux for $110 \mathrm{~h}$ and then cooled to room temperature. The mixture was filtered over Celite and washed with $\mathrm{MeCN}(20 \mathrm{~mL})$, and the filtrate was concentrated to $\sim 5 \mathrm{~mL}$. Subsequently, $\mathrm{Et}_{2} \mathrm{O}(10 \mathrm{~mL})$ was added, resulting in a yellow precipitate, which was collected, washed with $\mathrm{Et}_{2} \mathrm{O}(2 \times 15 \mathrm{~mL})$, and dried in vacuo. Yiel d: 0.25 g. The yellow solid was dissolved in acetone $(15 \mathrm{~mL})$, and $\mathrm{LiCl}$ (54 mg, $1.26 \mathrm{mmol}$ ) dissolved in $\mathrm{H}_{2} \mathrm{O}(1 \mathrm{~mL}$ ) was added. This mixture was stirred for $1 \mathrm{~h}$ at room temperature, resulting in the precipitation of a yellow solid. This solid was collected, washed with $\mathrm{H}_{2} \mathrm{O}(2 \times 15 \mathrm{~mL})$, acetone $(3 \times 20 \mathrm{~mL})$, and $\mathrm{Et}_{2} \mathrm{O}$ $(3 \times 20 \mathrm{~mL})$, and dried in vacuo, affording a brownish solid. Yield: $0.21 \mathrm{~g}(89 \%) .{ }^{1} \mathrm{H} N M R\left(\mathrm{CDCl}_{3}, 200 \mathrm{MHz}\right): \delta 7.90-6.97$ (br m, 120H, Ar H), 6.45 (br s, 12H, Ar H), 3.16 (br s, 24H, $\left.\mathrm{CH}_{2}\right) .{ }^{13} \mathrm{C} \mathrm{NMR}\left(\mathrm{CDCl}_{3}, 75 \mathrm{MHz}\right): \delta$ 128.5-146.1 (9 different $\operatorname{Ar~C}), 41.7 .{ }^{31} \mathrm{P} \mathrm{NMR}\left(\mathrm{CDCl}_{3}, 81 \mathrm{MHz}\right): \delta 34.29$.

Synthesis of Hexakis 4-(acetatopalladium)-3,5-bis[(pyrazol-1-yl)methyl]phenyl \} benzene (16). A solution of $\mathrm{Pd}(\mathrm{OAc})_{2}(0.34 \mathrm{~g}, 1.53 \mathrm{mmol})$ and $\mathbf{1 3}(0.36 \mathrm{~g}, 0.24 \mathrm{mmol})$ in AcOH $(20 \mathrm{~mL})$ was heated to $120^{\circ} \mathrm{C}$ and maintained at this temperature for $3 \mathrm{~h}$. The resulting brown solution was cooled to ambient temperature. Dropwise addition of $\mathrm{Et}_{2} \mathrm{O}$ eventually produced a precipitate. The mixture was centrifuged and the solution decanted. $\mathrm{Et}_{2} \mathrm{O}$ was added a second time until a precipitate formed, and the mixture was again centrifuged and decanted. $\mathrm{Et}_{2} \mathrm{O}(100 \mathrm{~mL})$ was added to the resultant pale brown solution, and the product precipitated as a tan solid. The solution was decanted and the product immediately washed with $\mathrm{Et}_{2} \mathrm{O}(2 \times 50 \mathrm{~mL})$ and then dried in vacuo, affording 16 as an off-white solid. Yield: $0.32 \mathrm{~g}(53 \%)$. ${ }^{1} \mathrm{H}$ NMR $\left(\mathrm{CDCl}_{3}, 300 \mathrm{MHz}\right): \delta 7.86$ (br s, $\left.12 \mathrm{H}, \mathrm{pz} \mathrm{H}\right), 7.15$ (br s, $12 \mathrm{H}$, pz H) , 6.49 (br s, 12H, pz H), 6.12 (s, 12H, Ar H), 4.54 (br s, $\left.24 \mathrm{H}, \mathrm{CH}_{2}\right), 2.02\left(\mathrm{~s}, 18 \mathrm{H}, \mathrm{CH}_{3} \mathrm{CO}\right) .{ }^{13} \mathrm{C} \mathrm{NMR}\left(\mathrm{CDCl}_{3}, 75 \mathrm{MHz}\right):$ $\delta$ 142.28, 135.10, 130.92, 129.14, 107.30, 57.81. Anal. Calcd for $\mathrm{C}_{102} \mathrm{H}_{90} \mathrm{~N}_{24} \mathrm{O}_{12} \mathrm{Pd}_{6}$ : C, 49.35; $\mathrm{H}, 3.65 ; \mathrm{N}, 13.54$. Found: $\mathrm{C}$, 49.09; H, 3.75; N, 13.38 .

Synthesis of Hexakis 4-(chloropalladium)-3,5-bis[(pyrazol-1-yl)methyl]phenyl $\}$ benzene (17). A solution of $\mathbf{1 6}(0.10$ $\mathrm{g}, 40 \mathrm{mmol}$ ) was prepared by dissolution of the complex in acetone $(30 \mathrm{~mL})$ and addition of $\mathrm{H}_{2} \mathrm{O}(3 \mathrm{~mL})$. $\mathrm{LiCl}(17 \mathrm{mg}, 0.4$ $\mathrm{mmol}$ ) was added to this solution, and the mixture was stirred at ambient temperature for $15 \mathrm{~h}$. After this time a brown precipitate had formed, the mixture was centrifuged, and the solution was decanted. The solid residue was washed with $\mathrm{H}_{2} \mathrm{O}$ $(50 \mathrm{~mL})$, acetone $(50 \mathrm{~mL})$, and $\mathrm{Et}_{2} \mathrm{O}(50 \mathrm{~mL})$ and then dried in vacuo, giving 17 as a brown solid. Yield: $70 \mathrm{mg}$ (74\%). Because the product was insoluble in common organic solvents, no
NMR data were obtained and the product was derivatized as the corresponding aqua complex 18.

Synthesis of Hexakis\{4-(aquapalladium)-3,5-bis[(pyrazol-1-yl)methyl]phenyl \} benzene Hexakis(tetrafluoroborate) (18). A solution of $\mathrm{AgBF}_{4}\left(82 \mathrm{mg}, 0.42 \mathrm{mmol}\right.$ ) in $\mathrm{H}_{2} \mathrm{O}$ $(0.5 \mathrm{~mL})$ was added to a stirred suspension of $\mathbf{1 7}(0.16 \mathrm{~g}, 70$ $\mathrm{mmol})$ in acetone $(50 \mathrm{~mL})$. The solution was stirred in the absence of light for $1 \mathrm{~h}$. The solvent was removed in vacuo, the residue was extracted with acetone $(50 \mathrm{~mL})$, and the product 18 was precipitated as a white-tan powder on addition of $\mathrm{Et}_{2} \mathrm{O}$. Yield: $0.17 \mathrm{~g}(89 \%)$. ${ }^{1} \mathrm{H}$ NMR (acetone- $\mathrm{d}_{6}, 300 \mathrm{MHz}$ ): $\delta 8.10\left(\mathrm{~d}, 3_{\mathrm{H}, \mathrm{H}}=2.10 \mathrm{~Hz}, 12 \mathrm{H}, \mathrm{pz} \mathrm{H}\right), 7.53(\mathrm{~s}, 12 \mathrm{H}, \mathrm{pz} \mathrm{H})$, 6.81 (s, 12H, Ar H), 6.49 (t, 12H, pz H), $5.18\left(\mathrm{~s}, 24 \mathrm{H}, \mathrm{CH}_{2}\right) .{ }^{13} \mathrm{C}$ NMR (acetone- $\left.d_{6}, 75 \mathrm{MHz}\right): \delta 141.34,137.59,132.94,129.19$, 107.01, 56.52. Anal. Calcd for $\mathrm{C}_{90} \mathrm{H}_{84} \mathrm{~B}_{6} \mathrm{~F}_{24} \mathrm{~N}_{24} \mathrm{O}_{6} \mathrm{Pd}_{6}$ : C, 39.21; H, 3.07; N, 12.19. Found: C, 39.06; H, 3.17; N, 12.11 .

Synthesis of 1,3,5-Tris 4-bromo-3,5-bis[(dimethylamino)methyl]phenyl $\}$ benzene (20). A modification of a literature procedure was used. ${ }^{20}$ To a stirred solution of 4-bromo3,5-bis[(di methylamino)methyl ]acetophenone (1.3 g, $8.7 \mathrm{mmol})$ in dry ethanol $(20 \mathrm{~mL})$ was added tetrachlorosilane $(5.0 \mathrm{~mL}$, $43.6 \mathrm{mmol}$ ) at $0{ }^{\circ} \mathrm{C}$. The reaction mixture was heated to reflux and kept at that temperature for $16 \mathrm{~h}$. The reaction mixture (a white suspension) was cooled to room temperature, and aqueous $\mathrm{HCl}(25 \mathrm{~mL}, 4 \mathrm{M})$ was added, resulting in a brown solution. This layer was washed with $\mathrm{CH}_{2} \mathrm{Cl}_{2}(2 \times 50 \mathrm{~mL})$, and an $\mathrm{NaOH}$ solution (4 M) was added until a pH of 13-14 was reached. Next, the aqueous layer was extracted with $\mathrm{CH}_{2} \mathrm{Cl}_{2}$ $(3 \times 50 \mathrm{~mL})$ and the combined organic fractions were dried over $\mathrm{Mg}_{2} \mathrm{SO}_{4}$. All vol atiles were evaporated in vacuo, affording a white sponge. The product was purified by recrystallization from hexane at $-30{ }^{\circ} \mathrm{C}$. Yield: $0.79 \mathrm{~g}(70 \%)$. ${ }^{1} \mathrm{H} \mathrm{NMR}\left(\mathrm{CDCl}_{3}\right.$, $200 \mathrm{MHz}): \delta 7.78(\mathrm{~s}, 3 \mathrm{H}, \mathrm{Ar} \mathrm{H}), 7.67(\mathrm{~s}, 6 \mathrm{H}, \mathrm{Ar} \mathrm{H}), 3.66(\mathrm{~s}$, $\left.12 \mathrm{H}, \mathrm{CH}_{2}\right), 2.35\left(\mathrm{~s}, 26 \mathrm{H}, \mathrm{CH}_{3}\right) .{ }^{13} \mathrm{C} \mathrm{NMR}\left(\mathrm{CDCl}_{3}, 75 \mathrm{MHz}\right): \delta$ $141.9,140.0,139.5,128.7,126.8,125.9,64.4,46.0$. MALDITOF-MS: $\mathrm{m} / \mathrm{z} 884.7\left([\mathrm{M}+\mathrm{H}]^{+}\right.$, calcd 883.2). Anal. Calcd for $\mathrm{C}_{42} \mathrm{H}_{57} \mathrm{Br}_{3} \mathrm{~N}_{6}$ : C, 56.96; $\mathrm{H}, 6.49 ; \mathrm{N}, 9.49$. Found: C, 56.82; $\mathrm{H}$, 6.56; N, 9.44 .

Synthesis of 1,3,5-Tris 4-(bromopalladium)-3,5-bis[(dimethylamino)methyl]phenyl \}benzene (21). Ligand 20 $(0.65 \mathrm{~g}, 0.73 \mathrm{mmol})$ and $\mathrm{Pd}(\mathrm{dba})_{2}(1.39 \mathrm{~g}, 2.40 \mathrm{mmol})$ were dissolved in benzene $(100 \mathrm{~mL})$ and stirred at room temperature for $20 \mathrm{~h}$. All volatiles were evaporated in vacuo, THF $(100 \mathrm{~mL})$ was added, and stirring was continued for $1 \mathrm{~h}$, affording a black precipitate. The mixture was filtered through Celite, and the filtrate was evaporated to dryness. The remaining solid was dissolved in $\mathrm{CH}_{2} \mathrm{Cl}_{2}(10 \mathrm{~mL})$, and $\mathrm{Et}_{2} \mathrm{O}(50 \mathrm{~mL})$ was added, yielding a yellow solid. This procedure was repeated three times, resulting in a light yellow solid. Yield: $0.63 \mathrm{~g} \mathrm{(72 \% ).}$ Analytically pure brownish crystals were obtained by slow diffusion of $\mathrm{Et}_{2} \mathrm{O}$ into a concentrated solution of the product in $\mathrm{CH}_{2} \mathrm{Cl}_{2} .{ }^{1} \mathrm{H} \mathrm{NMR}\left(\mathrm{CDCl}_{3}, 200 \mathrm{MHz}\right): \delta 7.53(\mathrm{~s}, 3 \mathrm{H}, \mathrm{Ar} \mathrm{H})$, 7.06 (s, 6H, $\mathrm{Ar} \mathrm{H}$ ), 4.06 (s, $\left.12 \mathrm{H}, \mathrm{CH}_{2}\right), 3.01,\left(\mathrm{~s}, 36 \mathrm{H}, \mathrm{CH}_{3}\right) .{ }^{13} \mathrm{C}$ NMR $\left(\mathrm{CDCl}_{3}, 75 \mathrm{MHz}\right): \delta 157.4,145.8,142.9,138.4,124.6$, 119.1, 74.8, 54.1. MALDI-TOF-MS: m/z $1128.6\left([\mathrm{M}-\mathrm{Br}]^{+}\right.$, calcd 1128.0). Anal. Calcd for $\mathrm{C}_{42} \mathrm{H}_{57} \mathrm{Br}_{3} \mathrm{~N}_{6} \mathrm{Pd}_{3}$ : C, 41.87; $\mathrm{H}$, 4.77; N, 6.97. Found: C, 42.03; H, 4.72; N, 6.88 .

Synthesis of 1,3,5-Tris 4-bromoplatinum-3,5-bis[(dimethylamino)-methyl]phenyl \}benzene (22): Ligand 20 $(0.60 \mathrm{~g}, 0.69 \mathrm{mmol})$ and $\left[\mathrm{Pt}(\mathrm{tol})_{2} \mathrm{SEt}_{2}\right]_{2}$ were mixed in benzene $(50 \mathrm{~mL})$, and this mixture was refluxed for $3 \mathrm{~h}$, resulting in a yell ow precipitate. The reaction mixture was cooled to room temperature, and all volatiles were evaporated. Next, the yell ow solid was extracted with $\mathrm{CH}_{2} \mathrm{Cl}_{2}(20 \mathrm{~mL})$ and $\mathrm{Et}_{2} \mathrm{O}$ was added, yielding a yellow precipitate. This yellow solid was collected, washed with $\mathrm{Et}_{2} \mathrm{O}(3 \times 20 \mathrm{~mL})$ and dried in vacuo. Yield: $0.74 \mathrm{~g} \mathrm{(73 \% ).}{ }^{1 \mathrm{H}} \mathrm{NMR}\left(\mathrm{CDCl}_{3}, 200 \mathrm{MHz}\right): \delta 7.59$ (s, $3 \mathrm{H}, \mathrm{Ar} \mathrm{H}), 7.11(\mathrm{~s}, 6 \mathrm{H}, \mathrm{Ar} \mathrm{H}), 4.09(\mathrm{~s}, 3 \mathrm{~J} \mathrm{Pt}, \mathrm{H}=22.0 \mathrm{~Hz}, 12 \mathrm{H}$, $\left.\mathrm{CH}_{2}\right), 3.16\left(\mathrm{~s},{ }^{3} \mathrm{Pt}, \mathrm{H}=18.0 \mathrm{~Hz}, 36 \mathrm{H}, \mathrm{CH}_{3}\right) .{ }^{13} \mathrm{C} \mathrm{NMR}\left(\mathrm{CDCl}_{3}\right.$, $50 \mathrm{MHz}$ ): $\delta 146.32,144.13,143.56,137.24,123.91,118.79$, 
77.72, 55.93. Anal. Calcd for $\mathrm{C}_{42} \mathrm{H}_{57} \mathrm{Br}_{3} \mathrm{~N}_{6} \mathrm{Pt}_{3}$ : C, 34.29; $\mathrm{H}, 3.91$; N, 5.71. Found: C, 34.38; H, 3.82; N, 5.66.

Synthesis of 1,3,5-Tris\{ 4-(aquapalladium)-3,5-bis[(dimethylamino)methyl]phenyl $\}$ benzene Tris(tetrafluoroborate) (23). To a solution of $\mathbf{2 1}$ in wet acetone $(20 \mathrm{~mL})$ was added $\mathrm{AgBF}_{4}(0.20 \mathrm{~g}, 1.0 \mathrm{mmol})$ in water $(1 \mathrm{~mL})$. This mixture was stirred for $30 \mathrm{~min}$ at room temperature and then filtered over Celite. The filtrate was concentrated, and the product was extracted into acetone $(20 \mathrm{~mL})$. Upon slow addition of $\mathrm{Et}_{2} \mathrm{O}$ $(20 \mathrm{~mL})$ a white precipitate was formed, which was collected and was dried in vacuo. Yield: $0.26 \mathrm{~g}(76 \%) .{ }^{1} \mathrm{H}$ NMR (acetone$\left.\mathrm{d}_{6}, 200 \mathrm{MHz}\right): \delta 7.72(\mathrm{~s}, 3 \mathrm{H}, \operatorname{Ar~H}), 7.32(\mathrm{~s}, 6 \mathrm{H}, \operatorname{Ar~H}), 4.23(\mathrm{~s}$, $\left.12 \mathrm{H}, \mathrm{CH}_{2}\right), 2.89\left(\mathrm{~s}, 36 \mathrm{H}, \mathrm{CH}_{3}\right) .{ }^{13} \mathrm{C} \mathrm{NMR}$ (acetone- $\mathrm{d}_{6}, 75$ $\mathrm{MHz}): \delta$ 150.94, 146.28, 142.89, 138.79, 124.26, 119.46, 73.62, 51.78. Anal. Calcd for $\mathrm{C}_{42} \mathrm{H}_{63} \mathrm{~B}_{3} \mathrm{~F}_{12} \mathrm{~N}_{6} \mathrm{O}_{3} \mathrm{Pd}_{3}$ : C, 39.42; $\mathrm{H}, 4.96$; N, 6.57. Found: C, 39.64; H, 5.20; N, 6.42.

Typical Catalytic Experiment. Ethyl $\alpha$-cyanoacetate $(0.17 \mathrm{~mL}, 1.6 \mathrm{mmol})$, methyl vinyl ketone $(0.40 \mathrm{~mL}, 4.8 \mathrm{mmol})$, diisopropylethylamine ( $28 \mu \mathrm{L}, 0.16 \mathrm{mmol}$ ), and $\mathbf{1 a}(3.2 \mathrm{mg}, 8$ $\mu \mathrm{mol}, 0.5 \mathrm{~mol} \%)$ were dissolved in $\mathrm{CH}_{2} \mathrm{Cl}_{2}(5 \mathrm{~mL})$, and the mixture was stirred at room temperature. The reaction mixture was sampled $(100 \mu \mathrm{L})$ at regular intervals, and the samples were worked up by evaporating all solvent and methyl vinyl ketone with a gentle stream of nitrogen. The conversion in the worked up samples was determined by ${ }^{1} \mathrm{H} N M R$ spectroscopy. Conversions obtained were confirmed by GC-MS analysis of the reaction mixture. All reactions which were complete within $22 \mathrm{~h}$ were repeated and isolated yields obtained by bulb-to-bulb distillation. For all reactions yields were found to be between 85 and $100 \%$.

Crystal Structure Determination of 21. Crystal data are as follows: $\mathrm{C}_{42} \mathrm{H}_{57} \mathrm{Br}_{3} \mathrm{~N}_{6} \mathrm{Pd}_{3}+$ solvent, $\mathrm{fw}=1204.87,{ }^{25}$ yellow block, $0.30 \times 0.30 \times 0.24 \mathrm{~mm}^{3}$, trigonal, $\mathrm{R} \overline{3} \mathrm{c}$ (No. 167), $\mathrm{a}=\mathrm{b}$ $=15.6134(2) \AA, c=35.2061(5) \AA, V=7432.64(17) \AA^{3}, Z=6$, $\rho=1.615 \mathrm{~g} / \mathrm{cm}^{3}$. A total of 32401 reflections were measured on a Nonius Kappa CCD diffractometer with a rotating anode $(\lambda=0.71073 \AA)$ at a temperature of $150(2) \mathrm{K}$. Of these, 1874 reflections were unique $\left(R_{\text {int }}=0.062\right){ }^{25}$ The absorption correction was based on multiple measured reflections (program PLATON , ${ }^{26}$ routine MULABS, $\mu=3.53 \mathrm{~mm}^{-1},{ }^{25}$ transmission

(25) Derived values do not contain the contribution of the disordered solvent. factors 0.34-0.39). The structure was solved with Patterson methods (DIRDIF 97) ${ }^{27}$ and refined with SHE LXL $97^{28}$ against $\mathrm{F}^{2}$ values of all reflections. Non-hydrogen atoms were refined freely with anisotropic displacement parameters. Hydrogen atoms were refined as rigid groups. The crystal structure contains large isolated voi ds at the crystallographic origin and its five symmetry-related positions ( $193 \AA^{3} /$ void, $1162 \AA^{3} /$ unit $^{2}$ cell) filled with disordered dichloromethane and diethyl ether molecules. Their contribution to the structure factors was secured by back-F ourier transformation (program PLATON, ${ }^{26}$ CALC SQUEEZE, 473 e/unit cell). There were 85 refined parameters, with no restraints. $\mathrm{R}$ values $(\mathrm{I}>2 \sigma(\mathrm{I}))$ : $\mathrm{R} 1=$ 0.0281 , wR $2=0.0670$. $R$ values (all reflections): $R 1=0.0288$, $\mathrm{wR} 2=0.0674$. GOF $=1.125$. The rest electron density was between -0.47 and $0.71 \mathrm{e} / \AA^{3}$. Molecular illustration, structure checking, and calculations were performed with the PLATON package. ${ }^{26}$

Acknowledgment. This work was supported in part (H.P.D., M.D.M., M.L., A.L.S.) by the Council for Chemical Sciences of The Netherlands Organization for Scientific Research (CW-NWO) and in part (J .P., A.J .C.) by the Australian Research Council. Dr. B. S. Williams (Utrecht University) is kindly acknowledged for stimulating discussions and critical comments.

Supporting Information Available: Tables giving crystal data and structure refinement details, positional and thermal parameters, and bond distances and angles for $\mathbf{2 1}$ This material is available free of charge via the Internet at http://pubs.acs.org.

\section{OM0101689}

(26) Spek, A. L. PLATON: A Multipurpose Crystallographic Tool; Utrecht University, The Netherlands, 2000.

(27) Beurskens, P. T.: Admiraal, G.: Beurskens, G.; Bosman, W. P. Garcia-Granda, S.; Gould, R. O.; Smits, J . M. M.; Smykalla, C. The DIRDIF 97 Program System, Technical Report of the Crystallography Laboratory; University of Nijmegen, Nijmegen, The Netherlands, 1997.

(28) Sheldrick, G. M. SHELXL-97: Program for Crystal Structure Refinement; University of Göttingen, Göttingen, Germany, 1997. 